\title{
Structural Studies of Peri-Interactions and Bond Formation Between Electron-rich Atomic Centres and $N$-Phenyl- carboxamides or Nitroalkenyl Groups.
}

\author{
Jane O'Leary, Xavier Formosa, Wolfgang Skranc and John D. Wallis ${ }^{*}$ \\ School of Biomedical and Natural Sciences, The Nottingham Trent University, \\ Clifton Lane, Nottingham NG11 8NS, UK.
}

\begin{abstract}
Structural studies of peri-interactions with dimethylamino groups in naphthalene systems indicate that the $N$-phenylcarboxamide group has a through-space electron attracting power closer to that of a carboxylic ester than a N,Ndialkylcarboxamide, while 2-nitroalkenyl groups have a lower through-space electron attracting power. However, addition of a benzoyl group to the 2-position of the nitroethenyl group leads to cyclisation to give a zwitterion, in which the carbanion is stabilised by full conjugation with the nitro group and partial conjugation with the carbonyl group. An interesting case where a steric interaction overrides an electrophile/nucleophile attraction is also described. The limitations to the interpretation of short contact distances from crystallographic measurements are discussed.
\end{abstract}

\section{Introduction.}

Interactions between molecules underpin many chemical processes both in biological systems and in materials chemistry, and include effects such as hydrogen bonding, charge transfer interactions and $\pi-\pi$ stacking. We have been interested in attractive interactions between electrophilic and nucleophilic groups. When pairs of such groups are forced close together, their interaction reveals the through-space electron attracting power of the electrophilic group, and may model a stage in the chemical reaction between the two groups. These studies have built on pioneering work in which incipient bond formation was recognised in medium ring compounds by Bürgi, Dunitz and Schefter ${ }^{1}$ and the principles of structure correlation developed and applied. ${ }^{2,3}$ The Xray crystal structures of naphthalenes $\mathbf{1}$ bearing a dimethylamino group and an electron deficient alkene or carbonyl substituent in the peri-positions show that the pyramidal 
dimethylamino group is oriented so that its lone pair lies in the space between the peri groups and the electrophilic group presents a face to the dimethylamino group, ${ }^{4-7}$ as originally demonstrated by Dunitz et al. ${ }^{4}$ The $1,5 \mathrm{Me}_{2} \mathrm{~N}---\mathrm{sp}^{2} \mathrm{C}$ separations decreases as the electron deficient group is changed from a $N, N$-dialkylamide e.g. 2 or 3 (2.764 and

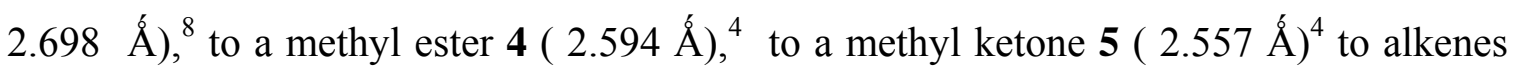
$-\mathrm{CH}=\mathrm{C}(\mathrm{CN}) \mathrm{CO}_{2} \mathrm{Et} 6(2.531 \AA \dot{A})^{7}$ and $-\mathrm{CH}=\mathrm{C}(\mathrm{CN})_{2} 7(2.413 \AA \dot{)}),^{5}$ and culminates in almost complete bond formation in the zwitterionic structure $\mathbf{8}^{5}$ where this separation is only 1.651(3) Á (Table 1). In contrast, when the dimethylamino group is replaced by the much less nucleophilic methoxy group, the $\mathrm{MeO}---\mathrm{sp}^{2} \mathrm{C}$ separations vary over a much smaller range $(2.55-2.62 \AA ̊)$, and any trend may be obscured by molecular distortions due to crystal packing. This led us to use the much more sensitive $\mathrm{Me}_{2} \mathrm{~N}---\mathrm{sp}^{2} \mathrm{C}$ separations to rank the unsaturated groups in an order of through space accepting ability (Table 1). Other peri interactions in naphthalene systems have been described, e.g. between electron-rich groups and alkynes ${ }^{12}$ or nitriles $^{13}$ and between dimethylamino groups and selenium halides ${ }^{14}$ or silicon centred groups. ${ }^{15}$ Of particular note is the use of the peri arrangement to force hydrogen bonding to an amide $\mathrm{N}$ atom's lone pair as a model for amide cleavage by cysteine proteases, ${ }^{16}$ as well as studies on proton sponges ${ }^{17}$ including their dynamics ${ }^{18}$ and the use of peri-naphthalenes as chiral auxiliaries. ${ }^{8}$ Akiba has used 1,8,9-trisubstituted anthracenes to extend studies to interactions of two methoxy groups with a carbocation centre, ${ }^{19}$ and interactions of two dimethylamino groups or two methoxy groups with a boron centre, including a measurement of the electron density distribution and topology for the latter case. ${ }^{19,20}$ Recently, Kirby has shown how the interaction between an amino and a carbonyl group in the solid state is promoted by hydrogen bonding to the carbonyl oxygen atom, ${ }^{21}$ Furthermore, he has studied this 


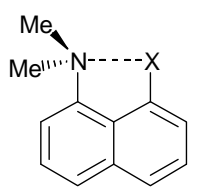

$1 X=\mathrm{sp}^{2} \mathrm{C}$

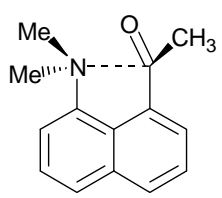

5

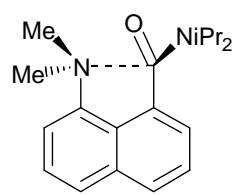

2

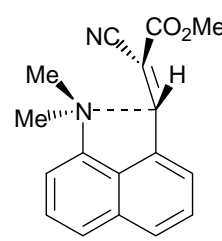

6

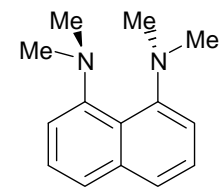

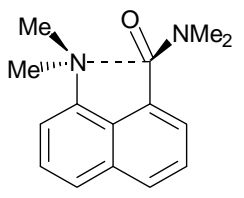

3

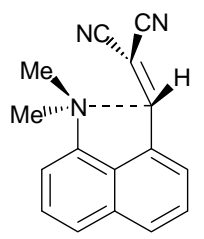

7

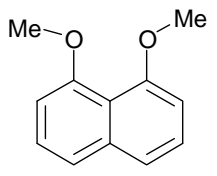

10
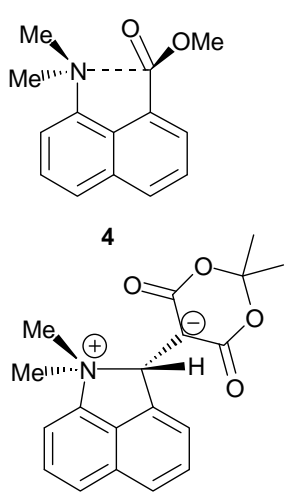

8

Table 1: $\mathrm{Me}_{2} \mathrm{~N}$---sp ${ }^{2} \mathrm{C}$ Separations in Peri-Naphthalenes 1

\begin{tabular}{|l|l|l|l|}
\hline $\mathrm{X}$ & Compound & $\mathrm{Me}_{2} \mathrm{~N}-----\mathrm{X}(\AA)$ & $\begin{array}{l}\text { MeO----X }(\AA) \text { in } \\
\text { corresponding methoxy- } \\
\text { naphthalene. }\end{array}$ \\
\hline $\mathrm{CON}(\mathrm{iPr})_{2}$ & $\mathbf{2}$ & $2.764(3)^{8}$ & $2.623(2)^{8}$ \\
\hline $\mathrm{CH}=\mathrm{CHBr}$ & $\mathbf{3}$ & $2.717(5)-2.758(2)^{9}$ & - \\
\hline $\mathrm{CONMe}{ }_{2}$ & & $2.698(3)^{8}$ & $2.597(5)^{4}$ \\
\hline $\mathrm{CH}=\mathrm{C}(\mathrm{COPh})_{2}$ & & $2.679(2)^{5}$ & - \\
\hline $\mathrm{CO}{ }_{2} \mathrm{H}$ & $\mathbf{4}$ & $2.606(5)^{4}$ & $2.559(4)^{4}$ \\
\hline $\mathrm{CO}{ }_{2} \mathrm{Me}$ & $\mathbf{5}$ & $2.594(4)^{4}$ & $2.588(3)^{10, \mathrm{a}}$ \\
\hline $\mathrm{COMe}$ & $\mathbf{6}$ & $2.557(3)^{4}$ & $2.606(9)^{4}$ \\
\hline $\mathrm{CH}=\mathrm{C}(\mathrm{CN}) \mathrm{CO}{ }_{2} \mathrm{Et}^{4}$ & & $2.531(2)^{7}$ & - \\
\hline $\mathrm{CHO}$ & $\mathbf{8}$ & $2.489(5)^{9}$ & $2.628(4)^{11, \mathrm{~b}} \& 2.644(4)^{11, \mathrm{c}}$ \\
\hline $\mathrm{CH}=\mathrm{C}(\mathrm{CN})_{2}$ & & $2.413(2)^{5}$ & $2.611(1)^{6}$ \\
\hline $\mathrm{CH}=\mathrm{C}((\mathrm{C}=\mathrm{O}) \mathrm{O}) \mathrm{CMe}{ }_{2}$ & $\mathbf{8}$ & $1.651(3)^{5}$ & $2.550(2)^{6}$ \\
\hline
\end{tabular}

${ }^{\mathrm{a}}$ For methyl 5,8-dimethoxynapthoate; ${ }^{\mathrm{b}}$ for 4,8-dimethoxy-5-(p-tosyloxy)-1-naphthaldehyde, ${ }^{\mathrm{c}}$ for 8methoxy- 5-(p-tosyloxy)-1-naphthaldehyde 
interaction type using an alicyclic system in which a high degree of bond formation between the groups is favoured by formation of an azaadamantane system. ${ }^{21}$

Determining the nature of the interaction between a particular pair of functional groups is not necessarily straightforward. However, as a rough guide, we proposed that the $\mathrm{Me}_{2} \mathrm{~N}---\mathrm{sp}^{2} \mathrm{C}$ interactions are attractive in nature if they are less than the corresponding $\mathrm{MeO}---\mathrm{sp}^{2} \mathrm{C}$ distance plus $0.15 \AA^{6}{ }^{6}$ The latter figure is the allowance for the larger size of the $\mathrm{N}$ atom over the $\mathrm{O}$ atom, and is estimated from the $\mathrm{Me}_{2} \mathrm{~N}---\mathrm{NMe}_{2}$ and $\mathrm{MeO}---\mathrm{OMe}$ distances in peri-naphthalene derivatives containing fragments 9 and 10. Thus, for the $\mathrm{CONMe}_{2}$ group, the $\mathrm{Me}_{2} \mathrm{~N}---\mathrm{sp}^{2} \mathrm{C}$ distance is just $0.05 \AA$ less than $\mathrm{d}\left(\mathrm{MeO}---\mathrm{sp}^{2} \mathrm{C}\right)+0.15 \AA$, and this interaction is interpreted as just having a very weak attractive component due to incipient addition to the carbonyl group, and that the separation is mainly determined by steric factors. In contrast, for the $\mathrm{CH}=\mathrm{C}(\mathrm{CN})_{2}$ group the $\mathrm{Me}_{2} \mathrm{~N}$----sp ${ }^{2} \mathrm{C}$ distance is $0.35 \AA$ less than $\mathrm{d}\left(\mathrm{MeO}---\mathrm{sp}^{2} \mathrm{C}\right)+0.15 \AA$, and this indicates a more attractive interaction. The rapidly developing field of charge density determinations from accurate X-ray diffraction data should provide rather more insight into incipient bond formation than this rather superficial approach. Indeed, charge densities of the amide $3^{22}$ and the dicyanoethene $7^{23}$ show $(3,-1)$ critical points in the charge density between the interacting groups with electron densities at those points of $0.11(1)$ and $0.19(2)$ e $\AA^{-3}$ respectively.

To expand the range of groups in this series we decided to investigate two areas. First, to examine the interaction with a N-phenylcarboxamide group, where the delocalization of the nitrogen atom's lone pair into the carbonyl group is moderated by 
conjugation with a phenyl group, by study of the molecular structures of compounds 1113. Secondly, to examine interactions with a $\beta$-nitroethenyl group, since nitro-activated alkenes were not represented in the series so far, and to examine the effect of adding a further terminal substituent.

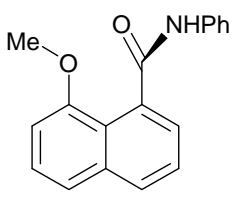

11

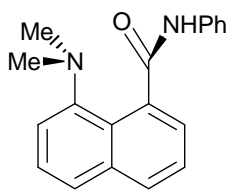

12

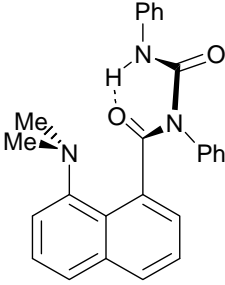

13

\section{Discussion.}

\section{N-Phenylnaphthamides 11 and 12, and N,N’-diphenyl-naphthoylurea 13.}

The N-phenylnaphthamides 11 and 12 containing peri methoxy or dimethylamino groups were prepared by peri-lithiation of the 1-methoxy- and 1dimethylaminonaphthalenes followed by reaction with phenyl isocyanate. A further compound 13 was isolated from the latter reaction, arising by addition of phenyl isocyanate to the first formed adduct to give an acyl urea group. This compound was included in the study because of the different electronic character of the amide carbonyl group presented to the dimethylamino group; this amide nitrogen atom shares its lone pair with a second carbonyl group. Molecular structures were measured by X-ray diffraction

at low temperatures (mostly $100-120 \mathrm{~K}$ ). Results are shown in Figures 1-3, and relevant molecular geometry are presented in Table 2 . Three polymorphs of the methoxy derivative 11 were measured, two triclinic $(\mathbf{1 1 A}$, measured at $100 \mathrm{~K}$, and 11C, measured at $150 \mathrm{~K})$ and one monoclinic $(\mathbf{1 1 B}$, measured at $100 \mathrm{~K})$. Each contained two 
independent molecules, and for 11C one molecule was disordered between two orientations $(85: 15)$.

Molecules 11-13 show the distortion pattern characteristic of such compounds, in which both substituents are splayed in the same direction, with the carbonyl containing group splayed outwards. The patterns of angles $\alpha-\varepsilon$ are similar for the three compounds and are comparable to the carbonyl derivatives discussed previously, in particular they compare closest to the carboxylic acid and ester derivatives. ${ }^{1,3}$ In the Nphenylnaphthamides 11 and $\mathbf{1 2}$ the phenyl groups lie syn to the carbonyl and the angles between the amide group and phenyl ring planes are in the range $23.6(3)-37.43(15)^{\circ}$ for 11 and $19.94(6)^{\circ}$ for $\mathbf{1 2}$, hence the amide $\mathrm{N}$ atom's lone pair can conjugate with the phenyl ring's $\pi$-system (Fig 1). Thus, the amide C-N bond lengths (11: 1.352(2) $\AA$ (average over six molecules) and 12: 1.3602(14) Á) are 0.02-0.03 Ál longer than that for a N-methylamide derivative $(1.329(10) \AA$ for 19 measurements at $\mathrm{T} \leq 150 \mathrm{~K}){ }^{24}$ The $\mathrm{C}($ phenyl)-N bond lengths are 1.424(2) and 1.4145(14) $\AA$ for $\mathbf{1 1}$ and 12, similar to $\operatorname{acetanilide}^{25}\left(1.417 \AA\right.$, angle between amide and phenyl planes: $\left.16.1^{\circ}\right)$.

The $\mathrm{Me}_{2} \mathrm{~N}$----C distance in $\mathbf{1 2}$ is 2.6049(15) $\AA$ which is similar to the corresponding separation for peri-interaction with a carboxylic ester or carboxylic acid, but considerably shorter than for the corresponding N,N-dimethylamide 3 (2.698(2) $\AA$ ). The MeO----C distances in N-phenylnaphthamide $11(2.574(2)-2.672(2) \AA$ ) have an average value of 2.637(2) $\AA$ which is shorter than the $\mathrm{Me}_{2} \mathrm{~N}----\mathrm{C}$ distance for 12 and the value of the parameter $\left[\mathrm{d}(\mathrm{MeO}----\mathrm{X})+0.15-\mathrm{d}\left(\mathrm{Me}_{2} \mathrm{~N}----\mathrm{X}\right)\right]$ for the $\mathrm{N}$ - 
phenylcarboxamide group is $0.18 \AA$. This suggests that the $\mathrm{Me}_{2} \mathrm{~N}$----sp ${ }^{2} \mathrm{C}$ interaction in 12 involves a significant attractive component, and the value for this parameter is a little
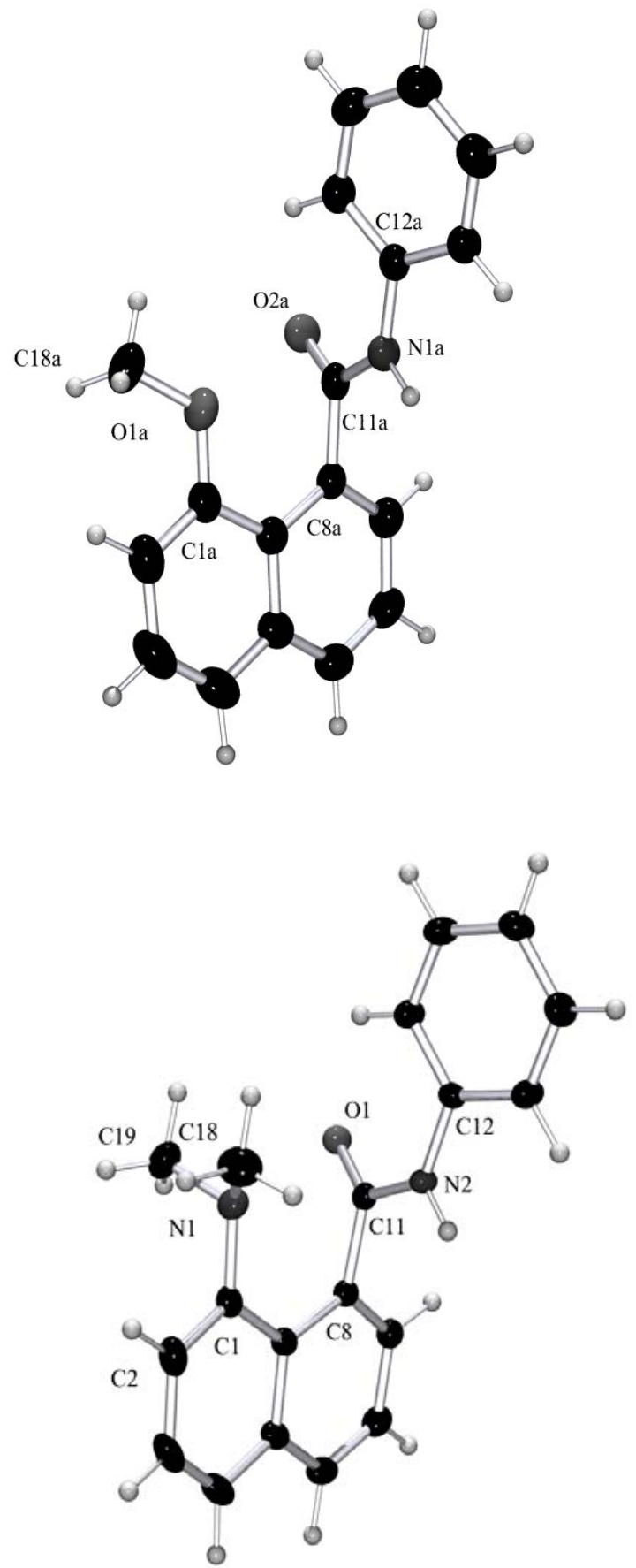

Figure 1. Views of $N$-phenylcarboxamides 11 (above) and 12 (below). 
larger than that of carboxylic ester $4(0.14 \AA)$, but much larger than that for a $N, N$ dimethylcarboxamide $(0.05 \AA)$, consistent with the reduced electron donation from the $\mathrm{N}$ atom into the carbonyl group. Further evidence of an attractive interaction in $\mathbf{1 2}$ comes from the orientation of the dimethylamino group, so that the theoretical axis of the $\mathrm{N}$ atom's lone pair axis lies at $15.1^{\circ}$ to the vector between peri nitrogen and carbonyl
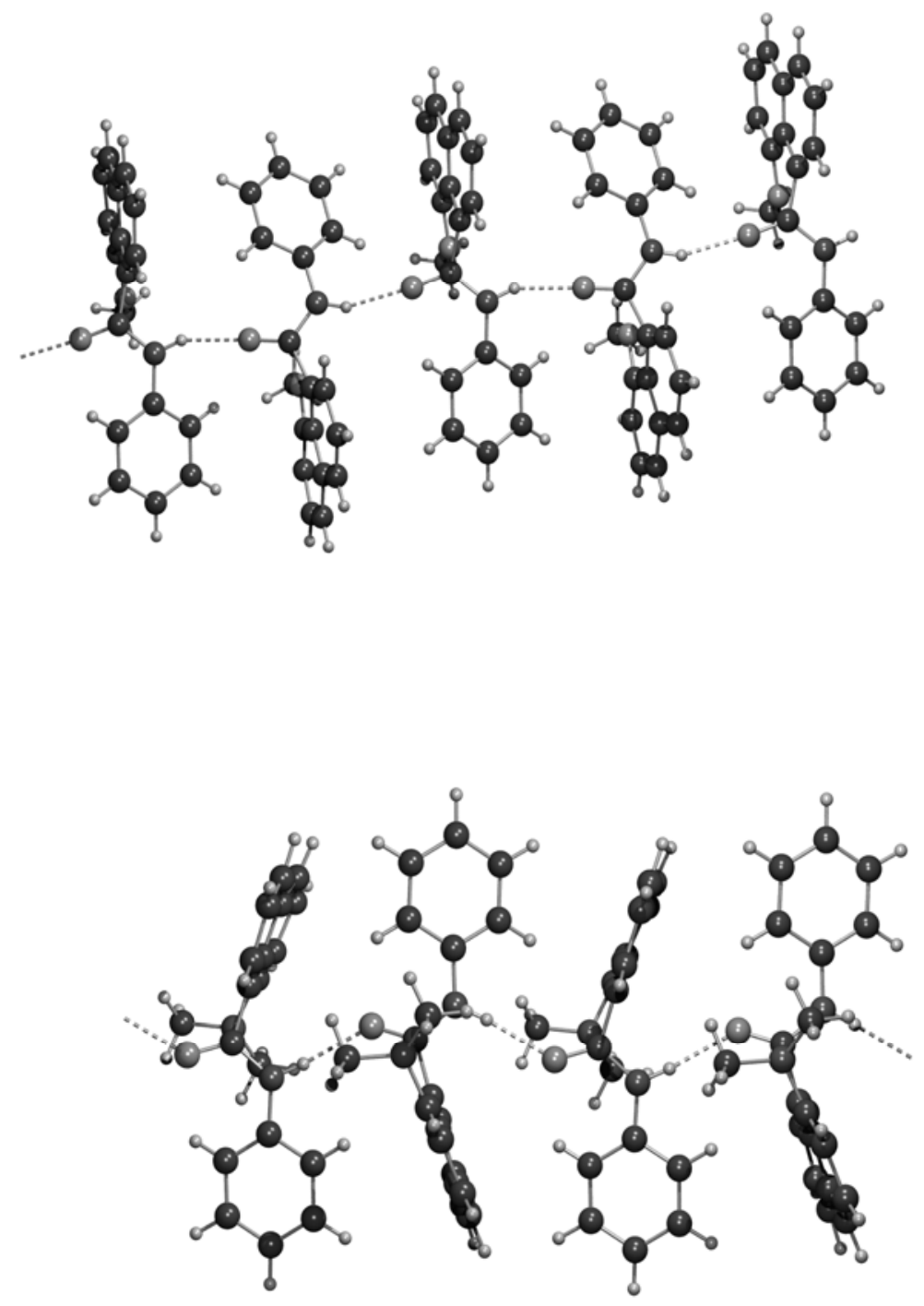

Figure 2. Hydrogen bonding of molecules in chains in polymorph 11A and 12 
carbon atoms. The crystal packings in $\mathbf{1 1}$ and $\mathbf{1 2}$ involve hydrogen bonding linking the amide groupings into chains (Fig. 2), and for all polymorphs of 11 the hydrogen bonding links the two independent molecules in a A-B-A-B fashion.

Table 2: Selected geometric data for compounds 11 - 13

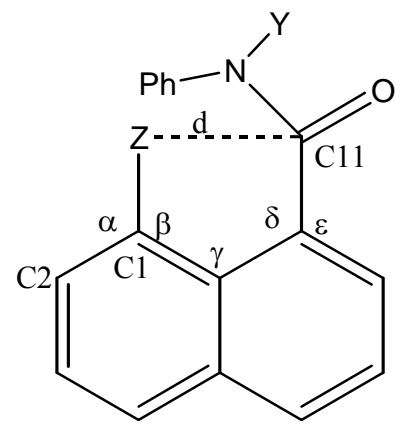

$\mathrm{Z}=\mathrm{OMe}(\mathbf{1 1}), \mathrm{NMe}_{2}(\mathbf{1 2}, \mathbf{1 3}) ; \mathrm{Y}=\mathrm{H}(\mathbf{1 1}, \mathbf{1 2}), \mathrm{Y}=\mathrm{CONHPh}(\mathbf{1 3})$

$\Delta \mathrm{C}$ : deviation of $\mathrm{C} 11$ from the plane of its substituents towards the peri substituent.

$\mathrm{T} 1$ and $\mathrm{T} 2$ : torsion angles of $\mathrm{O}-\mathrm{Me}(\mathbf{1 1})$ or N-Me bonds $(\mathbf{1 2} \& \mathbf{1 3})$ with the $\mathrm{C} 1-\mathrm{C} 2$ naphthyl bond.

\begin{tabular}{|c|c|c|c|c|c|c|c|c|c|}
\hline & $\mathrm{D}$ & $\alpha$ & $\beta$ & $\gamma$ & $\delta$ & $\varepsilon$ & $\Delta \mathrm{C}$ & $\mathrm{T} 1$ & $\mathrm{~T} 2$ \\
\hline \multirow[t]{2}{*}{$11 \mathrm{~A}$} & $2.6715(17)$ & $124.23(12)$ & $114.89(11)$ & $123.93(12)$ & $122.68(11)$ & $116.42(12)$ & $0.0332(14)$ & $0.4(2)$ & \\
\hline & $2.6708(18)$ & $123.90(12)$ & $115.10(11)$ & $123.68(12)$ & $122.68(11)$ & $116.70(11)$ & $0.0342(13)$ & $1.5(2)$ & \\
\hline \multirow[t]{2}{*}{ 11B } & $2.6540(16)$ & $124.18(12)$ & $114.68(11)$ & $123.80(11)$ & $123.24(11)$ & $116.04(11)$ & $0.0414(13)$ & $1.63(18)$ & \\
\hline & $2.6588(15)$ & $124.07(12)$ & $114.93(11)$ & $124.21(11)$ & $123.99(11)$ & $115.63(11)$ & $0.0401(14)$ & $0.30(18)$ & \\
\hline \multirow[t]{2}{*}{$11 C$} & $2.574(2)$ & $124.4(2)$ & $114.26(18)$ & $123.93(18)$ & $123.04(17)$ & $117.2(2)$ & $0.032(2)$ & $8.2(3)$ & \\
\hline & $2.590(3)$ & $123.7(2)$ & $114.2(2)$ & $123.4(2)$ & $124.4(2)$ & $115.7(2)$ & $0.047(3)$ & $8.8(5)$ & \\
\hline 12 & $2.6049(15)$ & $122.95(11)$ & $117.06(10)$ & $123.36(10)$ & $122.42(10)$ & $117.16(10)$ & $0.0555(12)$ & $49.18(16)$ & $-80.21(14)$ \\
\hline 13 & $2.6422(17)$ & $123.60(14)$ & $116.89(12)$ & $123.09(12)$ & $123.16(12)$ & $116.56(12)$ & $0.0502(15)$ & $27.22(19)$ & $-98.56(16)$ \\
\hline
\end{tabular}

The structure of molecule $\mathbf{1 3}$ contains some very interesting features (Figure 3 and 4). There is a hydrogen bond within the acyl urea grouping linking the terminal phenylamido group with the carbonyl group bonded to the naphthalene ring. The $\mathrm{H}----\mathrm{O}$ distance is 1.901(19) $\AA$, the N-H bond is 0.91(2) $\AA$ and the angles at the H and O atoms 
are $137.6(17)^{\circ}$ and $99.5(6)^{\circ}$ respectively. This completes a nearly planar six-membered ring system, which lies at $76.74(4)^{\circ}$ to the naphthalene ring's best plane (Figure 3 ). In fact, five atoms of this hydrogen bonded ring lie close to a plane (rms deviation $0.015 \AA$ ) from which the hydrogen bonded oxygen atom is slightly displaced (by 0.212(12) Á) in a direction away from the peri dimethylamino group. The two phenyl rings lie at $85.36(4)^{\circ}$ (ring A) and $13.21(8)^{\circ}$ (ring B) to the best plane through the six-membered urea ring system. Thus, the terminal nitrogen, N3, is involved in conjugation with phenyl ring $\mathrm{B}$, but the $\mathrm{N}$ atom located between two carbonyl groups, $\mathrm{N} 2$, is not conjugated with ring $\mathrm{A}$. 


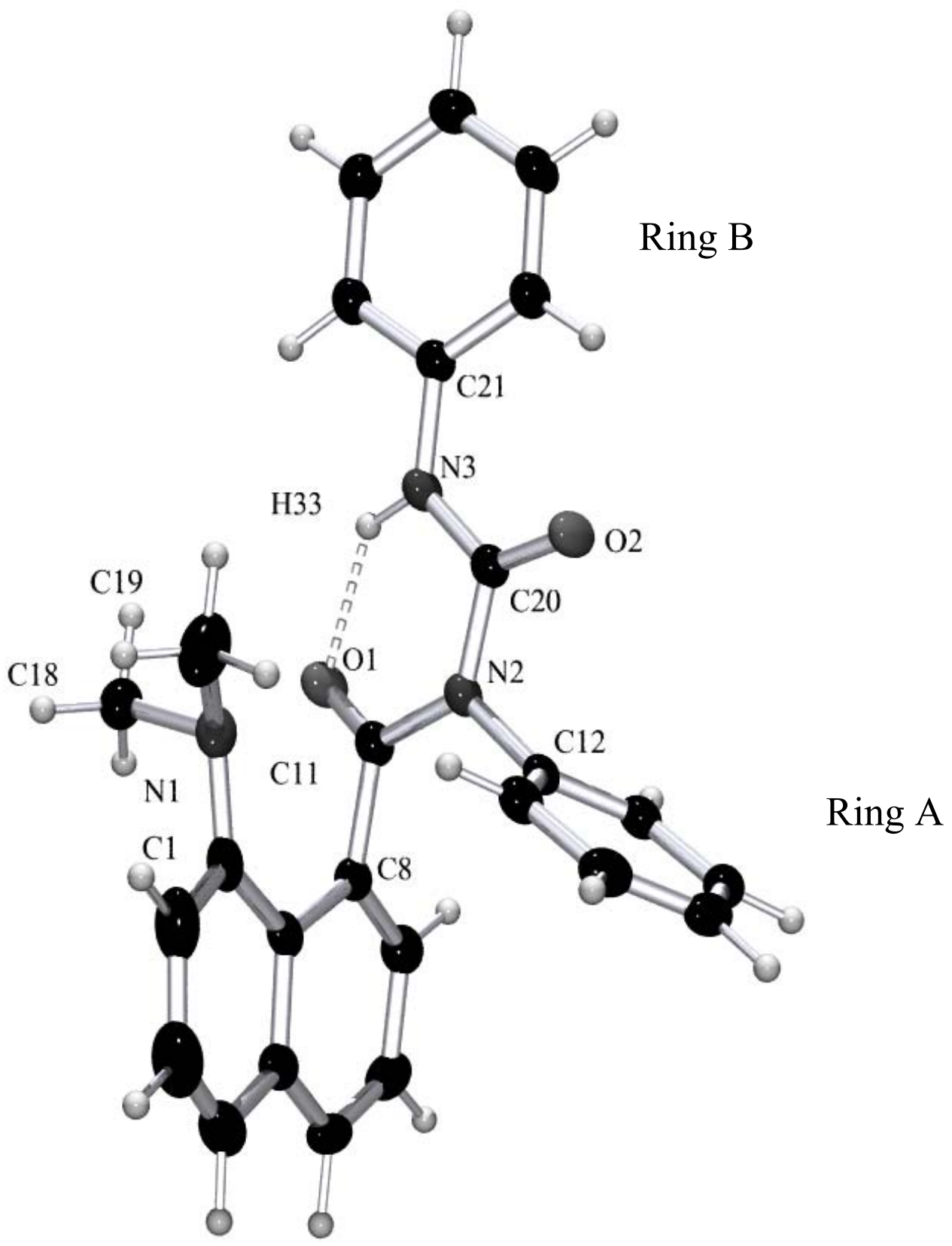

Figure 3. View of the acyl urea $\mathbf{1 3}$ showing the internal hydrogen bonding.

This is consistent with the longer $\mathrm{N}-\mathrm{C}(\mathrm{Ar})$ length to ring A than to ring B (1.4538(16) and 1.4205(17) Á respectively). The three N-C(carbonyl) bond lengths follow the expected 
pattern: the two bonds to N2 (N2-C11: 1.3890(16) and N2-C20: 1.4332(17) Á) are longer than the bond to N3 (N3-C20: 1.3530(17) $\AA$ ). For the two amide bonds from N2, the bond to $\mathrm{C} 20$ is considerably longer (by $0.044 \AA$ ) since this carbonyl C atom is already receiving electron density from $\mathrm{N} 3$, being part of a urea grouping. The ${ }^{1} \mathrm{H}$ NMR solution spectrum shows a very deshielded amide $\mathrm{H}$ atom $\left(\delta_{\mathrm{H}}: 11.60\right)$, and five shielded $\mathrm{H}$ atoms for phenyl ring $\mathrm{A}\left(\delta_{\mathrm{H}}: 6.84\right)$ which lies above the naphthalene ring system. The hydrogen bonded six-membered ring has been observed in many other acyl ureas systems, e.g. 14, ${ }^{26}$ and included in rotaxanes, ${ }^{27}$ biologically active materials like glimepiride ${ }^{28}$ and as features within large ring systems. ${ }^{29}$ Although no structures of acyl ureas with a $\mathrm{N}$-aryl group between the two carbonyls are reported, the closely related triphenylbiuret $15^{30}$ and its tri(2-tolyl) analogue ${ }^{31}$ have their central aryl ring at $70-71^{\circ}$ to the plane of the hydrogen bonded ring.

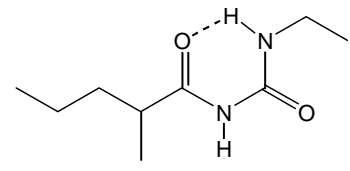

14

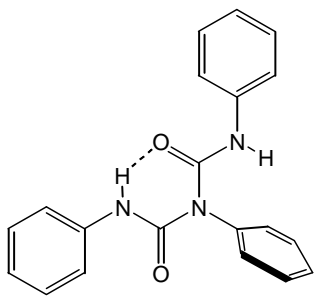

15

The $\mathrm{Me}_{2} \mathrm{~N}$---C separation for the acyl urea 13 is $2.6422(17) \AA$ which is $0.037(3) \AA$ longer than for the N-phenylcarboxamide 12, suggesting a weaker interaction. We have no methoxy analogue for the acyl urea, but since the $\mathrm{MeO}----\mathrm{C}$ separations are fairly insensitive to the nature of the electrophilic group, the methoxynaphthamide $\mathbf{1 1}$ can be used to estimate a value of $0.09 \AA$ for the parameter $\left[\mathrm{d}(\mathrm{MeO}----\mathrm{X})+0.15-\mathrm{d}\left(\mathrm{Me}_{2} \mathrm{~N}----\right.\right.$ $\mathrm{X})$ ] for the acyl urea grouping. Thus the $\mathrm{Me}_{2} \mathrm{~N}----\mathrm{sp}^{2} \mathrm{C}$ interaction in this compound also involves a small attractive component, but smaller than that observed in the N-phenyl 
naphthamide 12. Furthermore, in acyl urea $\mathbf{1 3}$ the torsion angles between the N-Me bonds and the $\mathrm{C} 1-\mathrm{C} 2$ bond of the naphthalene ring are $27.22(19)$ and $-98.56(16)^{\circ}$, hence the theoretical axis of the nitrogen lone pair lies at $24.9^{\circ}$ to the N1----C11 vector (cf. $15.1^{\circ}$ for 12). These results are rather surprising considering the electronic structure of the carbonyl group under attack. Thus, compared to the N-phenylnaphthamide 12, the peri carbonyl of the acyl urea might be expected to be more electron deficient, and thus make a stronger interaction with the dimethylamino group: N2 shares its lone pair electron density with a second carbonyl group, while in 12 the only alternative conjugating group is an in-plane phenyl group. This is reflected in the longer $\mathrm{N}$ $\mathrm{C}($ carbonyl) bond for $\mathbf{1 3}$ compared to 12: N2-C11, 1.3890(16) Á vs 1.3602(14) ̊́. However, in this case there is another factor to consider.

The phenyl ring A lies on the same side of the naphthalene plane as the dimethylamino methyl group $(\mathrm{C} 19)$ and there is a short contact between an ortho hydrogen (H13) of the phenyl ring and a methyl hydrogen. The H----H separation is only ca. 2.28 $\AA$, which corresponds to van der Waals contact. Indeed, it is a repulsion between the phenyl and methyl groups which has led to the longer $\mathrm{N}----\mathrm{sp}^{2} \mathrm{C}$ distance in $\mathbf{1 3}$ compared to that found in $\mathbf{1 2}$, and this compound does not provide an adequate model for assessing the interaction of a dimethylamino group with this particular peri carbonyl group. Additionally, this steric effect also restricts the orientation of the dimethylamino group such that the $\mathrm{N}$ atom's lone pair cannot be directed towards the peri group. In an attempt to ease the repulsion, the peri groups are displaced to opposite sides of the naphthalene plane. The sizes of the displacements from the naphthalene ring's best plane are $0.3683(16) \AA$ for the dimethylamino $\mathrm{N}$ atom and $-0.1919(17) \AA$ for the carbonyl C 
atom, which are larger than the corresponding displacements in N-phenylnaphthamide 12 (0.2389(15) and $-0.1529(15)$ for $\mathrm{N} 1$ and $\mathrm{C} 11$ respectively). The ${ }^{1} \mathrm{H}$ and ${ }^{13} \mathrm{C}$ NMR solution spectra of 13 show two distinct signals for the N-methyl groups $\left(\delta_{\mathrm{H}}: 2.57, \delta_{\mathrm{C}}\right.$ : 49.9 and $\left.\delta_{\mathrm{H}}: 2.98, \delta_{\mathrm{C}}: 43.7\right)$ due to the greater steric barrier for rotation of a peri group compared to the amide 12 which shows just one signal $\left(\delta_{\mathrm{H}}: 2.61, \delta_{\mathrm{C}}: 46.0\right)$. The methyl group involved in the steric interaction with the phenyl group is likely to have the more deshielded hydrogens. In solution it is much more difficult for the peri urea group of $\mathbf{1 3}$ to rotate about its bond to the naphthalene skeleton than for the amide group in $\mathbf{1 2}$.

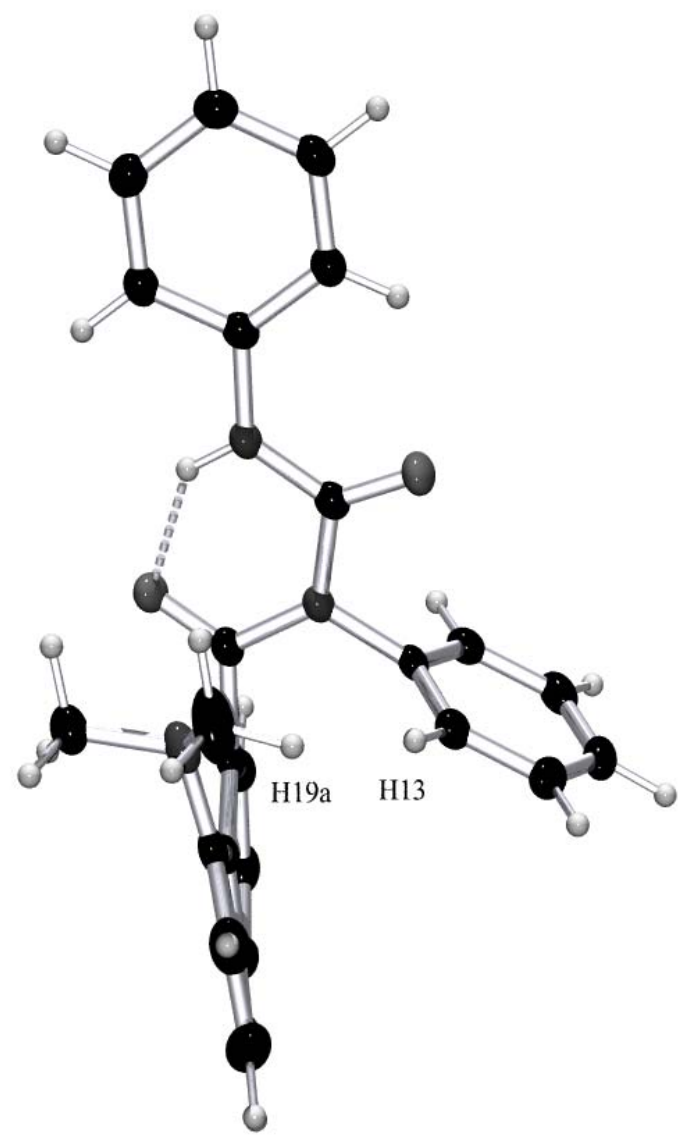

Figure 4. View of $\mathbf{1 3}$ showing the steric interaction between hydrogen atoms H19a and H13 and the displacement of the peri-substituents from the naphthalene plane. 
In summary, the structural measurements suggest that the $N$-phenylcarboxamide group has a through space electron attracting power significantly greater than a $N, N$ dialkylcarboxamide. The results for acyl urea 13 provide a cautionary tale about the need to carefully analyse a structure for all interactions, both steric and electronic. All three structures show small pyramidalisations of the carbonyl carbon towards the peri substituent: $0.029(2) \AA ̊$ in 11, 0.0555(12) $\AA$ in 12 and $0.0502(15) \AA$ in 13, the larger values for interaction with nitrogen, and the largest effect for the shorter contact to nitrogen. For 13 this contributes to the displacement of the carbonyl $\mathrm{O}$ atom out of the plane of the acyl urea. The $\mathrm{Nu}----\mathrm{C}=\mathrm{O}$ angles are $95.6(1)^{\circ}$ in $\mathbf{1 1}, 97.35(7)^{\circ}$ in 12 and $98.88(9)^{\circ}$ in $\mathbf{1 3}$, similar to those in related naphthalene systems.

\section{Nitroalkenes 17 and 18, and zwitterion 22.}
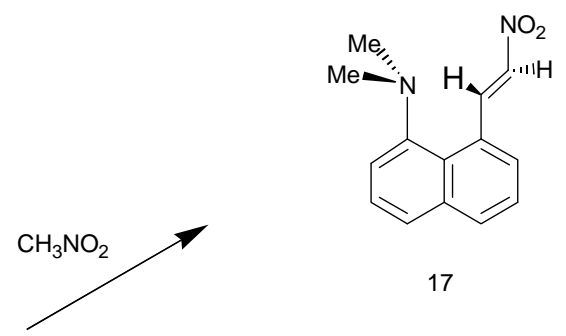
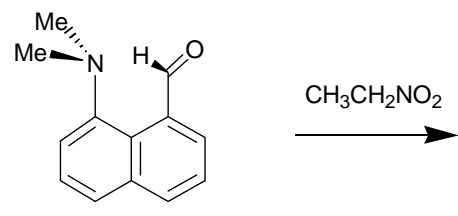

16

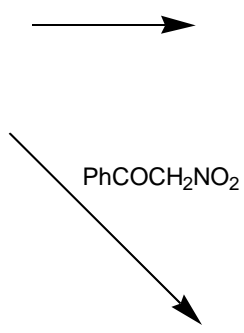

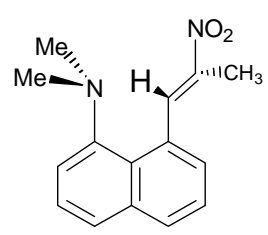

18

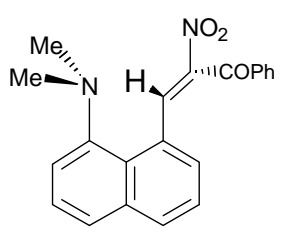

19 
To investigate the electron-withdrawing effect of a nitro group on the throughspace electron attracting power of an alkene bond, three 1-( $\beta$-nitroalkenyl)napththalene derivatives with peri-dimethylamino groups were selected for study. The first one, 17, contained the 2-nitroethenyl group and the second one, 18, contained an additional methyl group at the terminus of the alkene. Although electronically very similar to $\mathbf{1 7}$ the terminal methyl group is included to modify the orientation of the alkene by steric interaction with the ortho naphthalene $\mathrm{H}$ atom (Figure 4). It is already known that for cases where the peri interaction is weak, and the electrophilic group is either an alkene with a $\mathrm{H}$ atom cis to the naphthalene ring, e.g. 20, or an aldehyde such as $\mathbf{2 1}$, then the dominating interaction is optimisation of the conjugation of the alkene or carbonyl group with the naphthalene, so the double bond does not present a face clearly to the peri group. We wanted to be sure to include a compound where this did not happen, given its occurrence in the nitroethenyl derivative 20. The third compound $\mathbf{1 9}$ is selected since it is expected to have a more electron-deficient alkene due to the combination of terminal nitro and benzoyl groups. The compounds were prepared by Knoevenagel condensation on the aldehyde 16. It was notable that the crystals of $\mathbf{1 7}$ and $\mathbf{1 8}$ were dark orange in colour, but the crystals of the benzoyl nitro compound 19 were pale yellow. Low temperature X-ray analysis revealed that the latter contained almost complete bond formation between the functional groups and had a zwitterionic structure 22. Results are displayed in Figures 5-7, and selected molecular geometry in Table 3. 


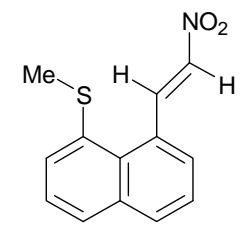

20

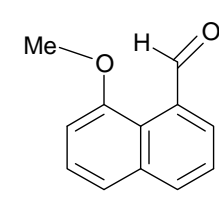

21

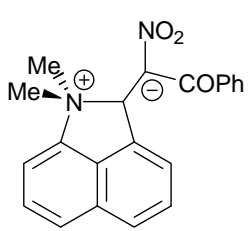

22

Table 3: Selected geometric data for compounds 17, 18 and 22.

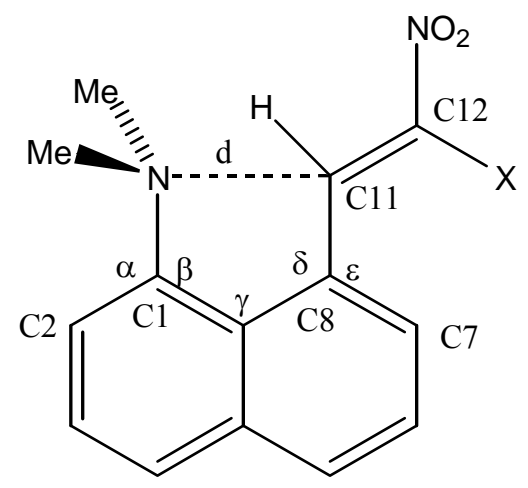

$\Delta \mathrm{C}$ : deviation of $\mathrm{C} 11$ from the plane of its substituents towards the peri substituent.

$\mathrm{T} 1$ and T2: torsion angles of $\mathrm{N}-\mathrm{Me}$ bonds with the $\mathrm{C} 1-\mathrm{C} 2$ aryl bond.

T3 torsion angle of C11-C12 bond with C7-C8 aryl bond.

\begin{tabular}{c|c|cccccc}
\hline & $\mathrm{X}$ & $\mathrm{D}$ & $\alpha$ & $\beta$ & $\gamma$ & $\delta$ & $\varepsilon$ \\
\hline \multirow{2}{*}{$\mathbf{1 7}$} & $\mathrm{H}$ & $2.6417(16)$ & $123.44(12)$ & $117.30(11)$ & $122.95(12)$ & $122.30(12)$ & $118.39(12)$ \\
& & & & & & & \\
$\mathbf{1 8}$ & $\mathrm{CH}_{3}$ & $2.6744(17)$ & $122.86(12)$ & $117.47(11)$ & $123.50(11)$ & $121.98(12)$ & $118.15(12)$ \\
& & & & & & & \\
$\mathbf{2 2}$ & $\mathrm{PhC}=\mathrm{O}$ & $1.6397(17)$ & $128.61(13)$ & $109.43(11)$ & $113.54(12)$ & $109.99(12)$ & $131.17(12)$ \\
\hline
\end{tabular}

\begin{tabular}{|c|c|c|c|c|c|}
\hline & $X$ & $\Delta \mathrm{C}$ & $\mathrm{T} 1$ & $\mathrm{~T} 2$ & $\mathrm{~T} 3$ \\
\hline 17 & $\mathrm{H}$ & $0.024(1)$ & $-26.67(18)$ & $103.13(15)$ & $50.52(19)$ \\
\hline 18 & $\mathrm{CH}_{3}$ & $0.042(1)$ & $25.95(19)$ & $-103.05(15)$ & $53.50(19)$ \\
\hline 22 & $\mathrm{PhC}=\mathrm{O}$ & $0.370(1)$ & $56.26(18)$ & $-65.87(18)$ & $50.8(2)$ \\
\hline
\end{tabular}


The structures of the two molecules $\mathbf{1 7}$ and 18, in which the peri-alkene group contains only one electron attracting substituent, adopt the $E$ configuration and have very similar molecular conformations. The nitro and alkene groups are almost coplanar, and the alkene bond makes torsion angles with the C1-C2 aromatic bond of 50.52(19) and $53.50(19)^{\circ}$ and so present a face to the dimethylamino group, in contrast to the methylthio analogue 20. The $\mathrm{Me}_{2} \mathrm{~N}---\mathrm{C}=\mathrm{CNO}_{2}$ separations of 2.6417(16) and 2.6744(17) $\AA$ place the $\beta$-nitroalkene group between the N-phenylcarboxamide group (N---C: $2.6049(15) \AA ̊)$ and N,N-dimethylcarboxamide group (N---C: 2.698(3) Á) in power of "through space" electron attracting ability, and similar to the $\mathrm{C}=\mathrm{C}(\mathrm{COPh})_{2}$ group $(\mathrm{N}---\mathrm{C}: 2.679(2) \AA ̊)$. (We were unable to obtain suitable crystals of the 8-methoxy analogue of $\mathbf{1 7}$ for a direct comparison of their peri interactions and calculation of the parameter $[\mathrm{d}(\mathrm{MeO}---\mathrm{X})+$ $\left.\left.0.15-\mathrm{d}\left(\mathrm{Me}_{2} \mathrm{~N}----\mathrm{X}\right)\right]\right)$. The dimethylamino groups in both nitroalkenes have similar orientations with the lone pair not well aligned with the $\mathrm{Me}_{2} \mathrm{~N}---\mathrm{C}$ vector; theoretical nitrogen lone pair axes lies at $27.6^{\circ}(\mathbf{1 7})$ and $28.6^{\circ}(\mathbf{1 8})$ to their N1---C11 vectors. One methyl group lies roughly perpendicular to the naphthalene plane. Similar orientations are observed in most cases with larger N---C separations, but for shorter N---C separations, e.g. in the esters and carboxylic acids the nitrogen lone pair approaches closer to the N--$\mathrm{C}$ vector. Compared to the N-phenylcarboxamide 12 the increased $\mathrm{Me}_{2} \mathrm{~N}$----sp ${ }^{2} \mathrm{C}$ separation is achieved by larger displacements of groups out of the naphthalene plane, rather than by in-plane displacements. There is always the question as to how much crystal packing effects influence the molecular conformations observed, this being a more significant problem when intramolecular attractions are at their weakest. In this particular case, it is notable that these electronically similar molecules have taken almost the same conformation, but in different crystallographic environments (C2/c cf. P21/n). The 
increase in the alkene bond length on addition of a methyl group (cf. 17: 1.3237(19) Á) v. 18: $1.3357(19) \AA$ ) is in line with the small amount of relevant data in the CSD which shows that nitroethenyl groups typically show short alkene bonds (1.303(35) $\AA$ for 6 structures) while additional of a $\mathrm{sp}^{3}$ carbon atom at the $\alpha$ position increases the bond length $(1.330(5) \AA \text { ) for } 6 \text { room temperature measurements. })^{24}$
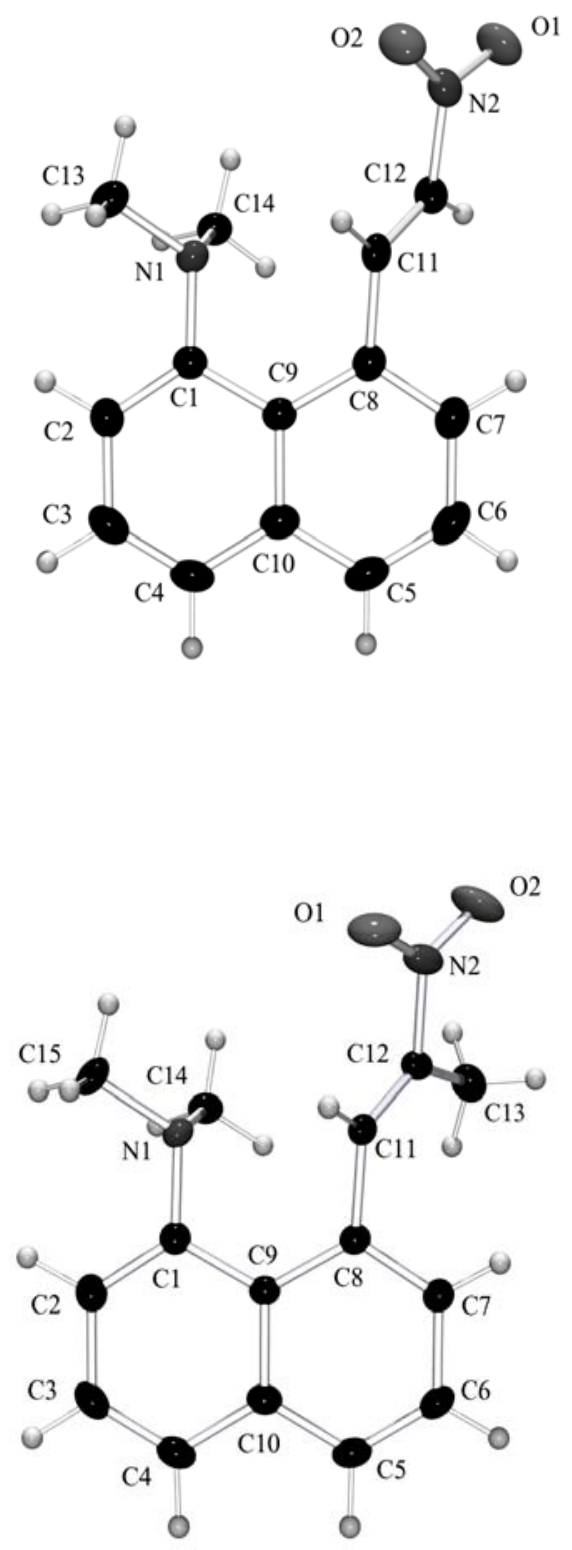

Figure 5. Views of the nitroalkenes 17 (above) and (b) 18 (below). 
In contrast, the addition of a benzoyl group to increase the electron attracting power of the double bond has led to the formation of a very interesting zwitterionic structure 22 with a new N-C bond 1.6397(17) Á long. This is slightly shorter than in the zwitterion $\mathbf{8}$, where the negatively charged centre is stabilized by two coplanar lactone groups (1.651(3) $⿱$ Á). The formal anionic centre at $\mathrm{C} 12$ has planar bonding geometry and is stabilized by the nitro and benzoyl substituents. The nitro group is better oriented for conjugation lying almost coplanar with the carbanionic centre: the angle between nitro group and this plane $[\mathrm{N} 2, \mathrm{C} 11, \mathrm{C} 12, \mathrm{C} 13]$ is only $2.02(14)^{\circ}$ while the carbonyl group lies at $40.59(8)^{\circ}$ to this plane. The benzene ring lies at $21.18(7)^{\circ}$ to the carbonyl group. Thus, delocalisation of electron density into the nitro group leads to a shortened C12-N2 bond of 1.3744(17) $\AA$ and lengthened $\mathrm{N}=\mathrm{O}$ bonds of $1.2623(15)$ and 1.2724(16) $\AA$, compared to C-N bonds: (1.512(4) $\AA$ ) and $\mathrm{N}=\mathrm{O}$ bonds (1.220(1) $⿱$ Á) in neutral nitro groups. ${ }^{24,32}$ In the tetrabutylammonium salt of 2-nitropropanate $23,{ }^{33}$ where the nitro group is the sole stabilizing group of the anionic charge, the C-N bond is shortened further to 1.311(7) $\AA$ and the $\mathrm{N}=\mathrm{O}$ bonds are lengthened more to 1.299(5) and 1.303(5) $\AA$, indicating that in zwitterion 22 the nitro group is not the only contributor to the stabilization of the negative charge. Even in the diisopropylammonium salt of diphenylnitromethanide $\mathbf{2 4},{ }^{34}$ the nitro group receives more electron density than in zwitterion 22 judging from the lengths of the $\mathrm{C}-\mathrm{N}(1.322(2) \AA \hat{)})$ and $\mathrm{N}=\mathrm{O}$ bonds (1.302(2) and 1.308(2) Á). There is no direct analogy in the Cambridge Structural Database for a carbanion stabilized by just a nitro group and one carbonyl group. In the potassium salt of carbanion $25^{35}$ in which three coplanar groups, nitro, cyano and a carboxylic ester, stabilise the negative charge, the bond lengths involving the nitro group 


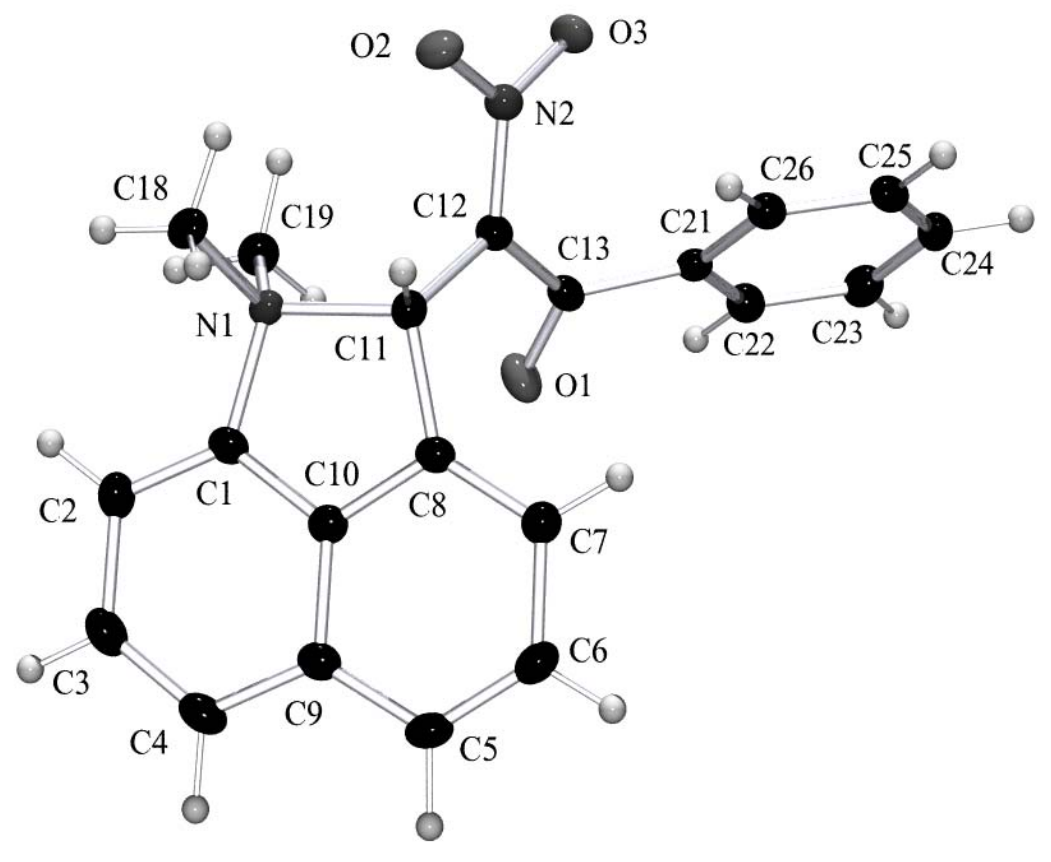

Figure 6. View of the zwitterion 22 perpendicular to the naphthalene plane.

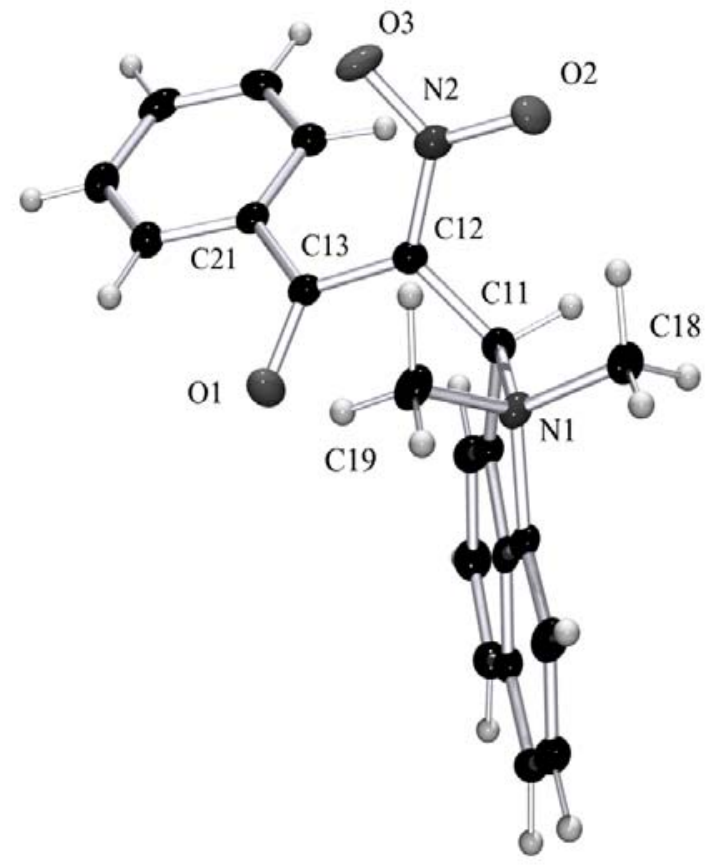

Figure 7. View of zwitterion 22 approximately perpendicular to the plane of the carbanionic centre. 
are similar to those observed in the zwitterion 22, i.e. $\mathrm{C}-\mathrm{N} 1.371(3) \AA$ and $\mathrm{N}=\mathrm{O}$ 1.246(3) and 1.270(3) Á. The carbonyl group in zwitterion 22 is a long way from lying planar to the carbanionic centre, nevertheless there is evidence of some conjugation between them. The carbonyl bond is lengthened a little to 1.2355(17) $\AA$ compared to an unperturbed benzoyl carbonyl bond (1.221(1) $\AA$ ). ${ }^{24}$ The length of the C12-C13 bond connecting the carbonyl group to the carbanionic centre $(1.4600(19) \AA$ ) is less than in a fully conjugated phenyl vinyl ketone $(1.480(12) \AA ̊$ for 8 structures at $\mathrm{T} \leq 150 \mathrm{~K}),{ }^{24}$ and substantially less than in an aliphatic $\alpha$-nitroketone $(1.544(6) \AA ̊$ for six structures at $\mathrm{T} \leq 150 \mathrm{~K}){ }^{24}$ In contrast to the zwitterion 22, for the uncoordinated enolate of acetophenone (as its potassium[12-crown-6] salt at $298 \mathrm{~K}),{ }^{36}$ the $\mathrm{C}=\mathrm{O}$ bond is much longer (1.291(13) Á) and the C-C bond is considerably shortened (1.393(16) $\AA$ ). The anion of nitroacetophenone is known in several transition metal complexes, where it binds through a carbonyl $\mathrm{O}$ atom and a nitro $\mathrm{O}$ atom. In the best determined structure, ${ }^{37}$ a complex with zinc, the bonds from the carbanionic centre are 1.365(4) $\AA$ for the C-N bond (cf $1.3744 \AA \AA$ in 22) and 1.385 (4) $\AA$ for the C-C bond to the carbonyl group. The latter is much shorter than in the zwitterion 22 where the carbonyl group lies out of the plane of the carbanionic centre, and there is no metal cation to enhance delocalization of charge to the oxygen atoms.

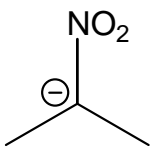

23

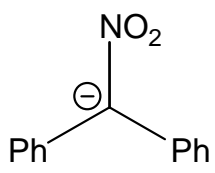

24

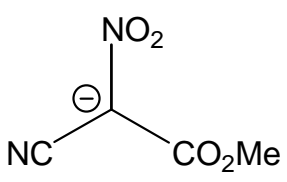

25

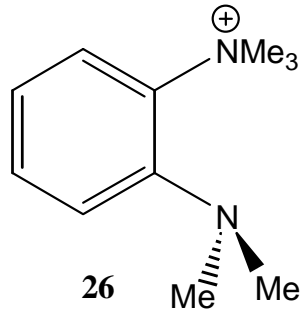


The five membered ring formed by cyclisation is close to planar with no torsion angle around the ring greater than $6^{\circ}$. The new bond may not be fully formed, in part due to the strain in the fused five membered ring. Furthermore, the alignment between the new $\sigma$ bond and the $\pi$ system at the carbanionic centre would permit some overlap of $\pi$ electron density with the $\sigma^{*}$ orbital. Is there a way of determining if the new bond between the peri groups is indeed fully formed? If it is not fully formed then the formal positive and negative charges on the zwitterion will be reduced from +1 and -1 . The NMe bond lengths can provide a clue. The cation 26 contains a benzene ring ortho substituted with a trimethylammonium group and a pyramidal dimethylamino group oriented so that its lone pair lies in the plane of the benzene ring. ${ }^{38}$ These two groups provide models for the dimethylamino group in the peri-naphthalene in question in its fully cyclised and non cyclised forms 22 and 19. In the tetraphenylborate salt of cation $\mathbf{2 6}^{38}$ at $150 \mathrm{~K}$ the N-Me bonds in the trimethylammonium group lie in the range 1.503(2)1.504(2) Á which are considerably longer than the N-Me bonds from the dimethylamino group 1.468(2)-1.470(2) Á. The N-Me bond lengths in the zwitterion 22 are 1.5022(18) and 1.5024(18) $\AA$. Although the measurement temperatures differ by $30 \mathrm{~K},{ }^{39}$ these results suggest that the bond formation in the zwitterion is at least close to completion. It is not so straightforward to make a similar analysis from the stabilization of the carbanion, with no very close model for comparison.

The delocalization of negative charge to the oxygen atoms of the nitro and benzoyl groups in zwitterion 22 may be stabilized by formation of weak hydrogen bonds involving carbon-bound hydrogen atoms. The benzoyl oxygen makes a surprisingly short contact $(2.235(16) \AA$ ) $)$ to H5 attached to the naphthalene ring of another molecule, with 
the four atoms involved not far from linear. Nitro oxygen atom O2 makes three contacts to hydrogens $\alpha$ to the cationic centre: two to methyl groups, one intermolecular $(\mathrm{O} 2---$ H19B, 2.481(16) Á) and one intramolecular (O2---H18A, 2.548(16) Á), as well as a 1,5 intramolecular contact to the methine H (O2---H11, 2.345(14) Á). Similarly O3 makes an intermolecular contact with a methyl group (O2---H18A, 2.457(17) Á).

NMR studies on 22 in DMSO- $\mathrm{d}_{6}$ show the presence of two sets of resonances in the ratio $3: 2$, both of which correspond to ring closed zwitterionic forms rather than the open chain alkene form. In particular, the methine $\mathrm{CH}$ grouping bonded to the positively charged nitrogen gives signals at $\delta_{C}: 94.3$ (major) and $\delta_{C}: 91.0$ (minor), and the attached hydrogen atom has resonances at $\delta_{\mathrm{H}}: 7.72$ (major) and $\delta_{\mathrm{H}}: 7.18 \mathrm{ppm}$. The corresponding atoms in the open chain compound 7 resonate at $\delta_{\mathrm{C}}: 165.7 \mathrm{ppm}$ and $\delta_{\mathrm{H}}: 8.75$. Furthermore, the N-methyl groups of 22 show signals at $\delta_{\mathrm{H}}: 3.60$ and $\delta_{\mathrm{C}}: 52.9$ and 53.1 , similar to those in zwitterion 8 ( $\delta_{\mathrm{H}}: 3.37$ and $\delta_{\mathrm{C}}: 51.8$ ), but quite different from those of the uncharged dimethylamino group in $7\left(\delta_{\mathrm{H}}: 2.69\right.$ and $\left.\delta_{\mathrm{C}}: 45.3\right)$. The two species present are likely to be rotamers arising from restricted rotation about the exocyclic $\mathrm{C}-\mathrm{C}$ bond. To interconvert while retaining the zwitterionic structure either benzoyl $\mathrm{O} 1$ or nitro O2 must rotate past methyl group $\mathrm{C} 19$. In the solid state conformation there are already short contacts involving these groups (O1---H19C: 2.519 Á; O2---H19B: $2.548 \AA$ ) $)$. The ${ }^{13} \mathrm{C}$ shifts of the carbanionic centres occur at $\delta_{C}: 116.5$ and 116.7 . In the pyrrolidinium salt of nitronate 27 , which has a cyano substituent to share the stabilization of the negative charge, the corresponding carbon resonates at $\delta_{C}: 96.7,{ }^{40}$ while in the sodium salts of simple nitronates such as 28 or 29 it resonates at $\delta_{C}: 112.3$ or $115.5 .^{41}$ The NMR spectra of zwitterion 22 in $\mathrm{CDCl}_{3}$ show two sets of resonances in a 4:1 ratio, 
with the methine $\mathrm{C}$ and $\mathrm{H}$ resonances at lower field: $\delta_{\mathrm{C}} 112.2$ (major) and 104.5 (minor) and $\delta_{\mathrm{H}}: 8.30$ (major) and 7.51 (minor) than in DMSO- $\mathrm{d}_{6}$. The difference in the shifts suggests that the precise degree of ring closure is affected by the solvent environment, with DMSO- $\mathrm{d}_{6}$ being better able to stabilize two larger charges. Further differences in the spectra are in line with this: thus, using the data for the major isomer in each case, the shifts for the two methyl groups in DMSO- $\mathrm{d}_{6}\left(\delta_{\mathrm{H}}: 3.58\right.$ and $\left.\delta_{\mathrm{C}}: 53.4\right)$ are further downfield than those in $\mathrm{CDCl}_{3} \quad\left(\delta_{\mathrm{H}}: 3.33\right.$ and $\left.\delta_{\mathrm{C}}: 51.7\right)$ and the ${ }^{1} \mathrm{H}$ shifts of the three hydrogens, ortho, meta and para to the positively charged $\mathrm{N}$ atom are also further downfield in DMSO-d $\mathrm{d}_{6}(8.06 \mathrm{~d}, 7.79 \mathrm{t}, 8.02 \mathrm{~d})$ than in $\mathrm{CDCl}_{3}(7.82 \mathrm{~d}, 7.58 \mathrm{t}, 7.41 \mathrm{~d})$. The carbanionic centre in $\mathrm{CDCl}_{3}$ occurs at $\delta_{\mathrm{C}}: 125.8$ for the main species.

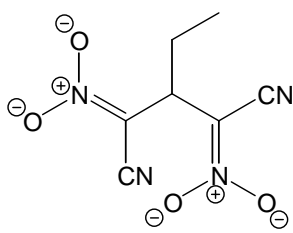

27

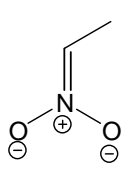

28

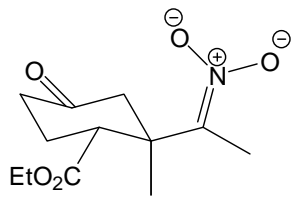

29

On heating a solution of 22 in $\mathrm{d}_{6}$-DMSO to $90^{\circ} \mathrm{C}$ for 48 hours, an intramolecular reaction took place to give the fused azepine 30. The structure shows two methylene groups with carbon shifts at $\delta_{C}: 41.6$ and 63.3 , assigned to the $4-$ and $2-\mathrm{C}$ respectively. The methylene hydrogens appeared as two broad signals for $4-\mathrm{H}_{2}$ which sharpened to an AB system on heating to $90{ }^{\circ} \mathrm{C}$, and a singlet for $2-\mathrm{H}_{2}$ which correlated to the carbon shift at $\delta_{\mathrm{C}}$ : 63.3. (In contrast, in $\mathrm{CDCl}_{3}$ at $24{ }^{\circ} \mathrm{C}$ the methylene hydrogens at position 2 appeared as an $\mathrm{AB}$ system which correlated to the carbon at $\delta_{\mathrm{C}} 63.5$, and the other methylene group gave a broad signal!) The structural assignment is further supported by a quaternary carbon at $\delta_{\mathrm{C}}$ : 99.9 for $3-\mathrm{C}$ and a molecular ion in the mass spectrum 
showing loss of a nitro group. A possible mechanism for this conversion is shown in the Scheme 2. Opening of the zwitterion by reversal of the Michael reaction to give the disubstituted naphthalene $\mathbf{1 9}$ is followed by hydride donation from a N-methyl group to the electron deficient alkene producing an iminium cation and a stabilized carbanion which then react together. The initial donation of hydride is facilitated by the close proximity of the groups and the electron-rich character of the dimethylamino group. Intermediate NMR spectra taken during the first hours of the rearrangement at $90{ }^{\circ} \mathrm{C}$ show the presence of at least one intermediate species. Although the spectra are complex, the singlets at 8.21 and 3.05 (broad) may provide evidence for the alkenyl hydrogen and dimethylamino groups of one isomer of the open chain form 19.

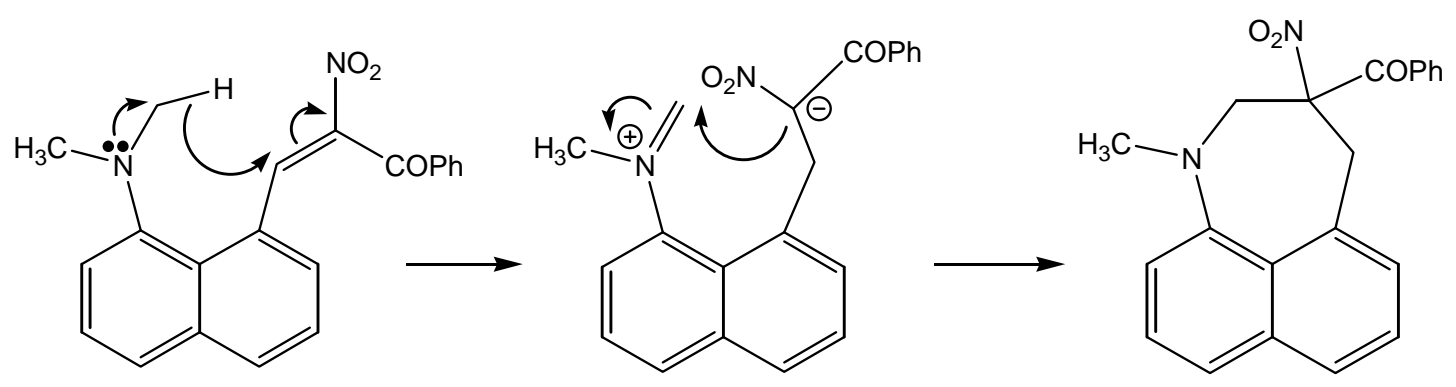

30

Scheme 2

Finally, one should consider whether it is really valid to use single crystallographic measurements to characterise interactions between dimethylamino groups and electrophilic groups. Are our observations really accurate or not? As we have pointed out before, ${ }^{6}$ crystal packing effects can provide small distortions to molecular structures which may compete with the effects of a weak interaction, and different crystalline environments in polymorphs may influence molecular geometry. Ideally, a number of different polymorphs or solvates should be measured (where they exist), or 
families of very closely related structures (e.g. bearing a small substituent remote from the groups involved in the interaction) should be measured. The existence of an interaction would be supported by the frequent occurrence of the feature, and the degree of accuracy of the method would be indicated by the spread of values for a particular interaction distance. We note the similarities of the interaction geometries in $\mathbf{1 7}$ and $\mathbf{1 8}$. Nevertheless, in the three polymorphs of compound $\mathbf{1 1}$ there are small differences in the MeO---C=O distances (11A: 2.672(2) \& 2.671(2), 11B: 2.6540(16) \& 2.6588(15), 11C: $2.574(2) \& 2.590(3) \AA$ ), even for the two which are measured at very similar temperatures (100 K for 11A and 11B, cf $150 \mathrm{~K}$ for 11C). The lack of any pronounced systematic variation in the $\mathrm{MeO}---\mathrm{sp}^{2} \mathrm{C}$ separations in a range of compounds (Table 1) suggests that any interaction is particularly weak, so it is perhaps not so surprising that this separation can be modified easily by external effects. This variability in the measured $\mathrm{MeO}---\mathrm{sp}^{2} \mathrm{C}$ separation for $\mathbf{1 1}$ also suggests that while comparison of the $\mathrm{Me}_{2} \mathrm{~N}$---sp ${ }^{2} \mathrm{C}$ separation with the $\mathrm{MeO}---\mathrm{sp}^{2} \mathrm{C}$ separation provides a useful qualitative comparison the parameters deduced are subject to considerable error. While we could assign error bars the parameter $\mathrm{d}\left(\mathrm{MeO}---\mathrm{sp}^{2} \mathrm{C}\right)+0.15-\mathrm{d}\left(\mathrm{Me}_{2} \mathrm{~N}---\mathrm{sp}^{2} \mathrm{C}\right)$ derived from the e.s.d.s of the compared atomic separations these would be very misleading, since the errors arising from crystal packing effects are considerably greater. The comparison of $\mathrm{Me}_{2} \mathrm{~N}$---sp ${ }^{2} \mathrm{C}$ separations in different peri-interactions is the simplest way of ranking interactions, though multiple measurements will provide a much sounder basis for identifying such trends. Thus, what we report here is more "the first indication" of interactions rather than the "last word". We may add that structures for comparison should be measured at low and similar temperatures to minimize the effects of thermal motion on the derived structural geometries. Indeed, some of the structures measured in 
the original pioneering work ${ }^{4}$ should now be remeasured to put the data in Table 1 on a more closely comparable basis. Lloyd-Jones has reported interesting initial investigations of estimating distances between peri-substituents using ${ }^{15} \mathrm{~N},{ }^{15} \mathrm{~N}$ coupling constants across hydrogen bonded amino groups, but correlation of calculated coupling constants with N,N separation was better than for the observed data. ${ }^{43}$

While our measurements in most cases indicate a short contact between dimethylamino and electrophilic groups, they do not give direct insight into the mode of the interaction. Only in 22 is there clear evidence for bond formation. It will be studies on the topology of the total electron density, determined either by X-ray diffraction measurements or by $a b$ initio calculations or both, which provide this, as in the alkynes studied earlier, ${ }^{42}$ or the recent work of Akiba ${ }^{19}$ or Lyssenko. ${ }^{22}$ Ab initio calculations have the advantage of treating an isolated molecule without interactions with its crystalline environment. Thus, structural studies on the interactions of a carboxylic acid group or its anion with the $\alpha$-nitrogen of a diazonium group in ortho-disubstituted aromatics ${ }^{44,45}$ have led Glaser to propose that the short contacts between these groups (O- - $\alpha-\mathrm{N}: 2.517-$ $2.621 \AA$ ) be described as 1,3 bridging interactions of the oxygen centre with the two atoms attached to the $\alpha$-nitrogen, since it is these two atoms which bear partial positive charges, while the $\alpha$-nitrogen bears a partial negative charge. ${ }^{44}$ Nucleophilic addition is known to occur at the $\beta$-nitrogen but addition to the $\alpha$-nitrogen would lead to the unstable 1,1-diazene system. ${ }^{46}$ Orbital overlap is not the only aspect of an interaction that need to be considered, especially with charged groups. Indeed, any interaction is determined by 
a composition of different effects e.g. electrostatic, as is the process of developing a new bond between two groups.

It is sometimes commented that if there is an attraction between two peri-groups then they should displaced towards each other; in 12, 13, 17 and 18 the dimethylamino group is displaced towards the electrophilic group which is displaced away. However, it is a matter of point of reference. The peri-hydrogen atoms of naphthalene lie at a separation of $2.44 \AA$ reflecting the separation of the carbon atoms $(2.48 \AA)$ to which they are attached, and the $\mathrm{H}---\mathrm{H}$ distance remains outside the sum of the van der Waals radii for two hydrogen atoms. ${ }^{47}$ The peri-disubstituted naphthalenes described here are somewhat different. The constraint applied by bonding to the naphthalene system acts to hold the groups well within the sum of their van der Waals radii, so that separations slightly greater than $2.5 \AA$ are still well within the van der Waals separation, and only indicate that at $2.5 \AA$ the interaction would be repulsive. It is of note that in the dicyanoethenyl derivative 7 the electrophilic group is not displaced away from the dimethylamino group and the $\mathrm{N}---\mathrm{C}$ separation is $2.413 \AA$. In summary, crystallographic studies are useful for identifying the existence of possible interactions, but these are only given credibility by multiple observations, and the underlying effects comprising the full interaction can only be more clearly unravelled by calculations and accurate electron density measurements. However, there is no substitute for experimental observations. 


\section{Experimental.}

General. NMR spectra were measured on a JEOL JNM-EX270 spectrometer at 270 $\mathrm{MHz}$ for ${ }^{1} \mathrm{H}$ and at $67.8 \mathrm{MHz}$ for ${ }^{13} \mathrm{C}$ using $\mathrm{CDCl}_{3}$ as solvent, and measured in p.p.m. downfield from TMS, unless otherwise stated. IR spectra were recorded on a PerkinElmer Spectrum RX 1 FT-IR spectrometer. Mass spectra were recorded at the EPSRC Mass Spectrometry Centre at Swansea University. X-Ray diffraction datasets were measured by the EPSRC National Crystallography Service at Southampton University. Chemical analysis data were obtained from Mr. T. Spencer, University of Nottingham. Flash chromatography was performed on 40-63 silica gel (Merck).

\section{8-Methoxy- N-phenyl-1-naphthamide 11}

$t$-Butyllithium $(1.7 \mathrm{M}$ solution in pentane, $20 \mathrm{ml}, 33 \mathrm{mmol})$ was added to a stirred solution of 1-methoxynaphthalene $(4.75 \mathrm{~g}, 30 \mathrm{mmol})$ in dry cyclohexane $(60 \mathrm{ml})$ at room temperature, under nitrogen. After $48 \mathrm{~h}$. the precipitated lithium salt was filtered under nitrogen and washed with dry ether. The lithium salt was suspended in dry ether and cooled to $-78^{\circ} \mathrm{C}$. Phenyl isocyanate $(3.57 \mathrm{~g}, 30 \mathrm{mmol})$ was added dropwise, the mixture allowed to warm to room temperature and stirred overnight. The resulting brown solution was poured on to aqueous $\mathrm{NH}_{4} \mathrm{Cl}$ and the white solid product collected by vacuum filtration to yield 11 (6.0 g, 72\%), m.p. $177-178^{\circ} \mathrm{C} .{ }^{1} \mathrm{H}$ NMR: $7.83(1 \mathrm{H}, \mathrm{m}, \mathrm{Ar}-$ $\left.H_{1}\right), 7.59\left(2 \mathrm{H}, \mathrm{d}, \mathrm{J}=7.9 \mathrm{~Hz}, \operatorname{Ar}-H_{2}\right), 7.47-7.38\left(5 \mathrm{H}, \mathrm{m}, \mathrm{Ar}-H_{4}+\mathrm{NH}\right), 7.34(2 \mathrm{H}, \mathrm{t}, \mathrm{J}=7.8$ $\left.\mathrm{Hz}, \mathrm{ArH}_{2}\right), 7.12\left(1 \mathrm{H}, \mathrm{t}, \mathrm{J}=7.3 \mathrm{~Hz}, \mathrm{Ar}-H_{1}\right), 6.85\left(1 \mathrm{H}, \mathrm{dd}, \mathrm{J}=6.9,1.5 \mathrm{~Hz}, \mathrm{Ar}-H_{1}\right), 3.79$ $\left(3 \mathrm{H}, \mathrm{s}, \mathrm{OCH}_{3}\right) ;{ }^{13} \mathrm{C}$ NMR: $170.0(\mathrm{C}=\mathrm{O}), 155.1,138.5,135.0,133.3,129.3,129.0,126.6$, $125.5,125.1,124.0,121.4,120.8,119.8,106.0\left(\mathrm{Ar}-C_{16}\right), 56.1\left(\mathrm{OCH}_{3}\right) ; v_{\max } / \mathrm{cm}^{-1}(\mathrm{KBr})$ : $3278,1654,1599,1549,1441,1324,1260,1120,1058,768,753$; Found: C, 77.9; H, 5.4; 
$\mathrm{N}, 4.9 \% \mathrm{C}_{18} \mathrm{H}_{15} \mathrm{NO}_{2}$ requires: C, 78.0; H, 5.5; N, 5.1\%; HRMS (EI): Found: 277.1107, $\mathrm{C}_{18} \mathrm{H}_{15} \mathrm{NO}_{2}$ requires: 277.1103 .

\section{8-(Dimethylamino)-N-phenyl-1-naphthamide 12 and N-(8-dimethylamino-1-} naphthoyl)-N,N'-diphenylurea 13

n-Butyllithium (1.6M solution in hexane, $26 \mathrm{ml}, 41 \mathrm{mmol})$ was added to a stirred solution of the 1-dimethylaminonaphthalene $(1.75 \mathrm{~g}, 10 \mathrm{mmol})$ in dry ether $(35 \mathrm{ml})$ at room temperature under nitrogen. After $48 \mathrm{~h}$. the precipitated lithium salt was filtered under nitrogen and washed with dry ether. The lithium salt was then suspended in dry ether and cooled to $-40^{\circ} \mathrm{C}$. Phenyl isocyanate $(1.67 \mathrm{~g}, 14 \mathrm{mmol})$ was added dropwise, the mixture was allowed to warm to room temperature and stirred overnight. The resulting yellow solution was poured on to aqueous $\mathrm{NH}_{4} \mathrm{Cl}$ and extracted with $\mathrm{CH}_{2} \mathrm{Cl}_{2}$. The organic solution was dried $\left(\mathrm{MgSO}_{4}\right)$, evaporated and the crude solid material separated on silica gel (hexane:ether, 2:1) to yield $12(0.68 \mathrm{~g}, 23 \%)$ and $13(1.92 \mathrm{~g}, 46 \%)$ as white solids.

\section{8-(Dimethylamino)-N-phenyl-1-naphthamide 12}

m.p. $193{ }^{\circ} \mathrm{C}{ }^{1} \mathrm{H}$ NMR: $7.87\left(1 \mathrm{H}, \mathrm{dd}, \mathrm{J}=8.2 \mathrm{~Hz}, \mathrm{Ar}-H_{1}\right), 7.66(1 \mathrm{H}, \mathrm{dd}, \mathrm{J}=8.1,1.1 \mathrm{~Hz}, \mathrm{Ar}-$ $\left.H_{1}\right), 7.57-7.29\left(8 \mathrm{H}, \mathrm{m}, \mathrm{Ar}-H_{8}\right), 7.17(1 \mathrm{H}, \mathrm{br} . \mathrm{s}, \mathrm{NH}), 7.08\left(1 \mathrm{H}, \mathrm{t}, \mathrm{J}=7.3 \mathrm{~Hz}, \mathrm{Ar}-H_{1}\right), 2.61$ $\left(6 \mathrm{H}, \mathrm{s}, \mathrm{N}\left(\mathrm{CH}_{3}\right)_{2}\right) ;{ }^{13} \mathrm{C}$ NMR: $169.8(\mathrm{C}=\mathrm{O}), 150.9,138.9\left(\mathrm{Ar}-\mathrm{C}_{2}\right), 135.3,134.5\left(1^{\prime}{ }^{-} \mathrm{C} \&\right.$ $\left.\operatorname{Ar}-C_{1}\right), 129.6\left(\operatorname{Ar}-C_{1}\right), 128.9\left(3^{\prime}-, 5\right.$ ' $\left.-C\right), 127.5,126.6,126.1,125.4,124.9\left(\mathrm{Ar}-C_{5}\right), 123.5$ (4'-C), 119.3 (2' '-,6'-C \& Ar- $\left.\left.C_{1}\right)\right), 46.0\left(\mathrm{~N}\left(\mathrm{CH}_{3}\right)_{2}\right) ; ; v_{\max } / \mathrm{cm}^{-1}(\mathrm{KBr}): 3268,1648,1595$, 1545, 1495, 1438, 1316, 778, 754, 712; HRMS (EI): Found: 290.1428, $\mathrm{C}_{19} \mathrm{H}_{18} \mathrm{~N}_{2} \mathrm{O}$ requires: 290.1419 . 


\section{N-(8-Dimethylamino-1-naphthoyl)-N,N'-diphenylurea 13}

m.p. $142{ }^{\circ} \mathrm{C} ;{ }^{1} \mathrm{H}$ NMR: $11.60\left(1 \mathrm{H}\right.$, br.s, NH), $7.66\left(2 \mathrm{H}, \mathrm{d}, \mathrm{J}=8.1 \mathrm{~Hz}, \operatorname{Ar}-H_{2}\right), 7.58(1 \mathrm{H}, \mathrm{d}$, $\left.\mathrm{J}=7.7 \mathrm{~Hz}, \operatorname{Ar}-H_{1}\right)$ 7.43-7.23 (7H, m, Ar- $\left.H_{7}\right), 7.12\left(1 \mathrm{H}, \mathrm{t}, \mathrm{J}=6.8 \mathrm{~Hz}, \operatorname{Ar}-H_{1}\right), 6.84(5 \mathrm{H}$, br.s, N-C $\left.\mathrm{H}_{5}\right), 2.98\left(3 \mathrm{H}, \mathrm{s},\left(\mathrm{NCH}_{3}\right), 2.57\left(3 \mathrm{H}, \mathrm{s}, \mathrm{NCH}_{3}\right) ;{ }^{13} \mathrm{C} \mathrm{NMR}: 175.5(\mathrm{~N}-\mathrm{C}=\mathrm{O})\right.$, $152.3\left(\mathrm{~N}_{2} \mathrm{C}=\mathrm{O}\right), 150.6,138.1,137.7,134.4,132.1,129.4,129.3,129.0,127.6,127.4$, 127.2, 126.4, 126.3, 124.6, 124.5, 123.8, 120.1, $117.7\left(\mathrm{Ar}-\mathrm{C}_{22}\right), 49.9\left(\mathrm{~N}\left(\mathrm{CH}_{3}\right)_{2}\right) ; v_{\max } / \mathrm{cm}^{-1}$ (KBr): 3442, 3265, 1705, 1661, 1495, 1282, 1194, 1159, 789, 765; Found: C, 75.9; H, 5.7; N, 10.1\%. $\mathrm{C}_{26} \mathrm{H}_{23} \mathrm{~N}_{3} \mathrm{O}_{2}$ requires: C, 76.3; H, 5.7; N, 10.3\%; HRMS (EI): Found: 409.1798, $\mathrm{C}_{26} \mathrm{H}_{23} \mathrm{~N}_{3} \mathrm{O}_{2}$ requires: 409.1790 .

\section{E-1-(8'-Dimethylaminonaphth-1'-yl)-2-nitroethene 17.}

Nitromethane $(0.3 \mathrm{ml}, 5.50 \mathrm{mmol})$ and ethylenediamine diacetate $(46 \mathrm{mg}, 0.25 \mathrm{mmol})$ were added to a solution of aldehyde $\mathbf{1 6}^{48}(0.50 \mathrm{~g}, 2.50 \mathrm{mmol})$ in dry methanol $(5 \mathrm{ml})$ under a nitrogen atmosphere and stirred together for $36 \mathrm{~h}$. at room temperature. The solvent was evaporated, and the residue purified by chromatography on silica eluting with ether/hexane (1:2) to give 17 as an orange solid, m.p. $139-140{ }^{\circ} \mathrm{C} .{ }^{1} \mathrm{H}$ NMR: $9.31(1 \mathrm{H}, \mathrm{d}$, $\mathrm{J}=13.1 \mathrm{~Hz}, 1-H), 7.88\left(1 \mathrm{H}, \mathrm{dd}, \mathrm{J}=7.9,1.5 \mathrm{~Hz}, \operatorname{Ar}-H_{1}\right), 7.62(1 \mathrm{H}, \mathrm{dd}, \mathrm{J}=8.0,1.2 \mathrm{~Hz}$, Ar- $\left.H_{1}\right), 7.51-7.25\left(4 \mathrm{H}, \mathrm{m}, \mathrm{Ar}-\mathrm{H}_{4}\right), 7.32(1 \mathrm{H}, \mathrm{d}, \mathrm{J}=13.1 \mathrm{~Hz}, 2-\mathrm{H}), 2.68\left(6 \mathrm{H}, \mathrm{s}, \mathrm{N}\left(\mathrm{CH}_{3}\right)_{2}\right.$; ${ }^{13}$ C NMR: $151.1\left(8^{\prime}-C\right), 143.9$ (1-C), 133.2 (2-C), 135.7, 131.2, 129.2, 128.4, 127.0, 126.7, 125.5, $124.9\left(\mathrm{Ar}-\mathrm{C}_{8}\right), 118.9\left(7^{\prime}-\mathrm{C}\right), 45.3\left(\mathrm{~N}\left(\mathrm{CH}_{3}\right)_{2}\right) ; v_{\max } / \mathrm{cm}^{-1}(\mathrm{KBr}): 1618,1519$, 1503, 1341, 970, 770, 762; m/z: (EI) $242\left(\mathrm{M}^{+}, 70\right), 196$ ([M-NO 2$\left.]^{+}, 100\right), 181$ (92), 166 (55); HRMS (EI) found 242.1060, $\mathrm{C}_{14} \mathrm{H}_{14} \mathrm{~N}_{2} \mathrm{O}_{2}$ requires 242.1055. 


\section{E-1-(8'-Dimethylaminonaphth-1'-yl)-2-nitropropene 18.}

Nitroethane $(0.01 \mathrm{ml}, 0.14 \mathrm{mmol})$ and ethylenediamine diacetate $(5 \mathrm{mg}, 0.03 \mathrm{mmol})$ were added to a solution of aldehyde $\mathbf{1 6}(0.10 \mathrm{~g}, 0.50 \mathrm{mmol})$ in dry methanol $(3 \mathrm{ml})$ under a nitrogen atmosphere and stirred together for $48 \mathrm{~h}$ at room temperature. The solvent was evaporated, and the residue purified by chromatography on silica eluting with cyclohexane/ethyl acetate $(10: 1)$ to give $\mathbf{1 8}(0.09 \mathrm{~g}, 68 \%)$ as an orange solid m.p. 68-69 ${ }^{\circ} \mathrm{C} .{ }^{1} \mathrm{H}$ NMR: $8.97(1 \mathrm{H}, \mathrm{s}, 1-H), 7.86\left(1 \mathrm{H}, \mathrm{d}, \mathrm{J}=8.1 \mathrm{~Hz}, \mathrm{Ar}-\mathrm{H}_{1}\right), 7.63(1 \mathrm{H}, \mathrm{dd}, \mathrm{J}=8.1$, $\left.1.2 \mathrm{~Hz}, \operatorname{Ar}-H_{1}\right), 7.49-7.44\left(2 \mathrm{H}, \mathrm{m}, \operatorname{Ar}-\mathrm{H}_{2}\right), 7.31\left(1 \mathrm{H}, \mathrm{dd}, \mathrm{J}=7.4,1.3 \mathrm{~Hz}, \operatorname{Ar}-H_{1}\right), 7.22$ $\left(1 \mathrm{H}, \mathrm{m}, \mathrm{Ar}-\mathrm{H}_{1}\right), 2.63\left(6 \mathrm{H}, \mathrm{s}, \mathrm{N}\left(\mathrm{CH}_{3}\right)_{2}\right), 2.33\left(3 \mathrm{H}, \mathrm{s}, 3-\mathrm{H}_{3}\right) ;{ }^{13} \mathrm{C}$ NMR: $151.3\left(8^{\prime}-\mathrm{C}\right)$, $141.3(2-C), 139.5(1-C), 135.6,129.8,129.5,127.3,126.5,125.3,124.8,\left(\operatorname{Ar}-C_{8}, 1\right.$ degeneracy), $118.9\left(7^{\prime}-\mathrm{C}\right), 45.5\left(\mathrm{~N}\left(\mathrm{CH}_{3}\right)_{2}\right), 13.3(3-\mathrm{C}) ; v_{\max } / \mathrm{cm}^{-1}: 2856,2827,2787$, 1653, 1516, 1455, 1426, 1387, 1321, 1025, 971, 775, 760; m/z: (EI) $256\left(\mathrm{M}^{+}, 20\right), 210$ ([M-NO $\left.]^{+}, 70\right), 195$ (100), 182 (43), 180 (45), 168 (35), 167 (30), 166 (38), 165 (30); HRMS (EI) found 256.1209, $\mathrm{C}_{15} \mathrm{H}_{16} \mathrm{~N}_{2} \mathrm{O}_{2}$ requires 256.1212.

\section{1,1-Dimethylbenzo(cd)indolium-2-benzoylnitromethide 22.}

Benzoylnitromethane ( $1.24 \mathrm{~g}, 7.50 \mathrm{mmol})$ and ethylenediamine diacetate $(62 \mathrm{mg}, 0.342$ mmol) were added to a solution of aldehyde 16 ( $0.68 \mathrm{~g}, 3.42 \mathrm{mmol})$ in dry methanol (10 $\mathrm{ml}$ ) under a nitrogen atmosphere and stirred together for $28 \mathrm{~h}$. at room temperature. The resulting precipitate was filtered and washed with methanol to give $22(0.89 \mathrm{~g}, 75 \%)$ as a yellow powder (from methanol), m.p. $161-162{ }^{\circ} \mathrm{C} . \quad v_{\max } / \mathrm{cm}^{-1}(\mathrm{KBr}): 1610,1577,1450$, $1408,1321,1309,1190,1176,1106,1083,954,812,796,777,736,710,641 ; \mathrm{m} / \mathrm{z}$ (APCI): $347\left([\mathrm{M}+\mathrm{H}]^{+}, 100\right), 301(22) ; \quad H R M S(\mathrm{ES})$ found 347.1392 for $[\mathrm{M}+\mathrm{H}]^{+}$, $\mathrm{C}_{21} \mathrm{H}_{19} \mathrm{~N}_{2} \mathrm{O}_{3}$ requires 347.1396. 
${ }^{1} \mathrm{H}$ NMR (400 MHz, DMSO-d 6 ): 3:2 mixture of isomers, major component $8.06(1 \mathrm{H}, \mathrm{d}$, $\mathrm{J}=8 \mathrm{~Hz}, 8-H), 8.02(1 \mathrm{H}, \mathrm{d}, \mathrm{J}=8 \mathrm{~Hz}, 6-H), 7.88(1 \mathrm{H}, \mathrm{d}, \mathrm{J}=8.2 \mathrm{~Hz}, 5-H), 7.79(1 \mathrm{H}, \mathrm{t}$, $7.8 \mathrm{~Hz}, 7-H), 7.72(1 \mathrm{H}, \mathrm{s}, 2-H), 7.61(1 \mathrm{H}, \mathrm{dd}, \mathrm{J}=8.2,7.2 \mathrm{~Hz}, 4-H), 7.49(2 \mathrm{H}, \mathrm{dm}, \mathrm{J}=$ 8.2 Hz, 2'-,6'-H ), 7.32-7.40 (3H, m, 3'-, 4'-5'-H), $7.25(1 \mathrm{H}, \mathrm{dd}, \mathrm{J}=6.8,1.2 \mathrm{~Hz}, 3-H)$, $3.58\left(6 \mathrm{H}, \mathrm{s}, \mathrm{N}\left(\mathrm{CH}_{3}\right)_{2}\right)$, minor component $8.06(1 \mathrm{H}, \mathrm{d}, \mathrm{J}=8 \mathrm{~Hz}, 8-\mathrm{H}), 8.03(1 \mathrm{H}, \mathrm{d}, \mathrm{J}=7$ Hz, 6-H), $7.92(1 \mathrm{H}, \mathrm{d}, \mathrm{J}=8.2 \mathrm{~Hz}, 5-\mathrm{H}), 7.78(1 \mathrm{H}, \mathrm{t}, \mathrm{J}=7.9 \mathrm{~Hz}, 7-H), 7.72(1 \mathrm{H}, \mathrm{t}$ (partly obscured), J = 7.7 Hz, 4-H), 7.57 (2H, m, 2'-,6'-H), 7.32-7.40 (5H, m, 3'-,4'-5'-H), 7.39 $(1 \mathrm{H}, \mathrm{d}$ (obscured), 3- $\mathrm{H}), \quad 7.18(1 \mathrm{H}, \mathrm{s}, 2-\mathrm{H}), \quad 3.58\left(6 \mathrm{H}, \mathrm{s}, \mathrm{N}\left(\mathrm{CH}_{3}\right)_{2}\right) ;{ }^{13} \mathrm{C}$ NMR $(100$ MHz, DMSO- $\left.\mathrm{d}_{6}\right)$ : major component $188.8(\mathrm{C}=\mathrm{O}), 147.4(8 \mathrm{a}-\mathrm{C}), 143.0\left(1^{\prime} \mathrm{C}\right), 135.0$ (2a-C), $131.2(5 a-C), 130.1 \& 130.0$ (4-,4'-C), 128.7 (8b-C), 128.4 (7-C), 127.8 (2'-3',5'-,6'-C), 126.8 (6-C), 124.2 (5-C), 119.0 (3-C), 116.5 ( $\left.{ }^{-C}-\mathrm{NO}_{2}\right), 114.5$ (8-C), 94.3 (2C), $53.4\left(\mathrm{~N}-\left(\mathrm{CH}_{3}\right)_{2}\right)$; minor component $189.2(\mathrm{C}=\mathrm{O}), 147.7(8 \mathrm{a}-\mathrm{C}), 143.2\left(1^{\prime} \mathrm{C}\right), 135.8$ (2a-C), 131.3 (5a-C), 130.3 \& 129.2 (4-,4'-C), 128.7 (8b-C), 128.3 (7-C), 127.7 (2'-3',5'-,6'-C), 126.9 (6-C), 123.9 (5-C), 118.5 (3-C), 116.7 ( $\left.{ }^{-C}-\mathrm{NO}_{2}\right), 114.2$ (8-C), 91.0 (2C), $52.9\left(\mathrm{~N}-\left(\mathrm{CH}_{3}\right)_{2}\right) ; \quad{ }^{1} \mathrm{H}$ NMR $\left(400 \mathrm{MHz}, \mathrm{CDCl}_{3}\right): 4: 1$ mixture of isomers, main component $8.30(1 \mathrm{H}, \mathrm{s}, 2-\mathrm{H}), 7.82(1 \mathrm{H}, \mathrm{d}, \mathrm{J}=8.3 \mathrm{~Hz}, 8-\mathrm{H}), 7.78(1 \mathrm{H}, \mathrm{d}, \mathrm{J}=8.0 \mathrm{~Hz}, 5-$ H), $7.74\left(2 \mathrm{H}, \mathrm{d}, \mathrm{J}=8.0 \mathrm{~Hz}, 2^{\prime}-, 6^{\prime}-\mathrm{H}\right), 7.58(1 \mathrm{H}, \mathrm{t}, \mathrm{J}=7.7 \mathrm{~Hz}, 7-\mathrm{H}), 7.46(1 \mathrm{H}, \mathrm{t}, \mathrm{J}=8.0$ Hz, 4-H), 7.45 (1H, t, J = 7.4 Hz, 4'-H), 7.41 (1H, d, J-value obscured, 6-H), 7.37 (2H, t, $\left.\mathrm{J}=7.4 \mathrm{~Hz}, 3^{\prime}-, 5^{\prime}-\mathrm{H}\right), 7.20(1 \mathrm{H}, \mathrm{br} \mathrm{d}, \mathrm{J}=7.0 \mathrm{~Hz}, 3-\mathrm{H}), 3.33\left(6 \mathrm{H}, \mathrm{s}, \mathrm{N}\left(\mathrm{CH}_{3}\right)_{2}\right) ;{ }^{13} \mathrm{C} \mathrm{NMR}$ (100 MHz, $\left.\mathrm{CDCl}_{3}\right)$ : main component $188.9(\mathrm{C}=\mathrm{O}), 148.0(8 \mathrm{a}-\mathrm{C}), 140.4\left(1^{\prime} \mathrm{C}\right), 133.2$ (2aC), 130.8 (5a-C), 127.2-130.7, (4-,7-,8b, 2'-3'-,4'-,5'-,6'-C), 126.8 (5-C), 123.7 ('C$\left.\mathrm{NO}_{2}\right), 121.9$ (3-C), $115.2(6-\mathrm{C}), 112.4(2-\mathrm{C}), 51.7\left(\mathrm{~N}-\left(\mathrm{CH}_{3}\right)_{2}\right)$. 


\section{Conversion of 22 to 30 .}

On heating a solution of 22 for $48 \mathrm{~h}$ in $\mathrm{d}_{6}$-DMSO an intramolecular reaction yielded a single compound whose structure is proposed as 3-benzoyl-N-methyl-3-nitro-1,2,3,4tetrahydronaphth[1,8-bc]azepine 30, ${ }^{1} \mathrm{H}$ NMR $\left.(400 \mathrm{MHz}, \text { DMSO-d })_{6}\right): 7.83(2 \mathrm{H}, \mathrm{d}, \mathrm{J}=$ $\left.8.0 \mathrm{~Hz}, 2^{\prime}-, 6^{\prime}-H\right), 7.73(1 \mathrm{H}, \mathrm{dd}, \mathrm{J}=8.3,1.0 \mathrm{~Hz}, 7-H), 7.73\left(1 \mathrm{H}, \mathrm{t}, \mathrm{J}=7.4 \mathrm{~Hz}, 4^{\prime}-H\right), 7.59$ $\left(2 \mathrm{H}, \mathrm{t}, \mathrm{J}=7.8 \mathrm{~Hz}, 3^{\prime}-, 5^{\prime}-H\right), 7.41(1 \mathrm{H}, \mathrm{dd}, \mathrm{J}=7.7,0.8 \mathrm{~Hz}, 8-\mathrm{H}), 7.34(1 \mathrm{H}, \mathrm{t}, \mathrm{J}=7.7 \mathrm{~Hz}$, 9-H), $7.30(1 \mathrm{H}, \mathrm{t}, \mathrm{J}=7.6 \mathrm{~Hz}, 6-H), 7.13(1 \mathrm{H}, \mathrm{br} \mathrm{d}, \mathrm{J}=6.8 \mathrm{~Hz}, 5-H), 6.90(1 \mathrm{H}, \mathrm{d}, \mathrm{J}=7.3$ $\mathrm{Hz}, 10-H), 4.28\left(1 \mathrm{H}\right.$, br) \& $4.18(1 \mathrm{H}$, br $)\left(\text { at } 90{ }^{\circ} \mathrm{C} \text {, an } \mathrm{AB} \text { system, } \mathrm{J}=16 \mathrm{~Hz}, 4-\mathrm{H}_{2}\right)^{*}$, $4.15\left(2 \mathrm{H}, \mathrm{s}, 2-\mathrm{H}_{2}\right), 3.03\left(3 \mathrm{H}, \mathrm{s}, \mathrm{N}-\mathrm{CH}_{3}\right) ; \quad{ }^{13} \mathrm{C} \mathrm{NMR}\left(100 \mathrm{MHz}, \mathrm{DMSO}-\mathrm{d}_{6}\right): 191.2$ $(\mathrm{C}=\mathrm{O}), 151.1(10 \mathrm{a}-C), 135.9\left(4^{\prime}-C\right), 134.2(7-C), 134.1(7 \mathrm{a}-C), 131.6(4 \mathrm{a}-C), 129.5$ (3',5'-C), 128.7 (2'-,6'-C), 128.3 (4'-C), 128.0 (5-C), 126.7 (10b-C), 126.2 (9-C), 125.8 (6C), $121.1(8-C), 110.2(10-C), 99.9(3-C), 63.3(2-C), 41.6(4-C), 41.4\left(\mathrm{~N}-\mathrm{CH}_{3}\right)$. Addition of water to the sample precipitated a small amount of 30, ${ }^{1} \mathrm{H}$ NMR $(270 \mathrm{HMz}$, $\left.\mathrm{CDCl}_{3}\right): 7.77\left(2 \mathrm{H}, \mathrm{d}, \mathrm{J}=7.9 \mathrm{~Hz}, 2{ }^{\prime}-, 6^{\prime}-\mathrm{H}\right), 7.60(1 \mathrm{H}, \mathrm{dd}, \mathrm{J}=8.3,1.1 \mathrm{~Hz}, 7-H), 7.54(1 \mathrm{H}$, t, J = 7.4 Hz, 4'-H), $7.41\left(2 \mathrm{H}, \mathrm{t}, \mathrm{J}=7.4 \mathrm{~Hz}, 3^{\prime}-5^{\prime}-\mathrm{H}\right), 7.16-7.31(3 \mathrm{H}, \mathrm{m}, 6-, 8-, 9-\mathrm{H})$ $7.02(1 \mathrm{H}, \mathrm{br} d, \mathrm{~J}=6.3 \mathrm{~Hz}, 5-H), 6.78(1 \mathrm{H}, \mathrm{dd}, \mathrm{J}=7.2,1.5 \mathrm{~Hz}, 10-H), 4.15(2 \mathrm{H}, \mathrm{br}, 4-$ $H), 4.06(2 \mathrm{H}, \mathrm{AB}$ system, $\mathrm{J}=15.3 \mathrm{~Hz}, 2-\mathrm{H}) * 3.00\left(3 \mathrm{H}, \mathrm{s}, \mathrm{CH}_{3}\right) ;{ }^{13} \mathrm{C} \mathrm{NMR}(67.8 \mathrm{MHz}$, $\left.\mathrm{CDCl}_{3}\right): 189.7(\mathrm{C}=\mathrm{O}), 150.9(10 \mathrm{a}-C), \quad 135.9\left(4^{\prime}-C\right), 133.9$ (7-C), $133.6(7 \mathrm{a}-C) 131.3$ (4a-C), $129.0\left(3^{\prime}-, 5^{\prime}-C\right), 128.5\left(2^{\prime}-, 6^{\prime}-C\right), 128.2\left(4^{\prime}-C\right), 128.0$ (5-C), 126.4 (10b-C), 125.7 (9-C), $125.6(6-C), 121.0(8-C), 109.3$ (10-C), 99.5 (3-C), 63.5 (2-C), 41.7 (4C), $41.0\left(\mathrm{~N}-\mathrm{CH}_{3}\right) ; m \mid z(\mathrm{EI}) 346\left(\mathrm{M}^{+}, 35\right), 301$ (32), $300\left(\left[\mathrm{M}-\mathrm{NO}_{2}\right]^{+}, 30\right), 285$ (15), 196 (32), 195 ([M-NO $\left.\left.{ }_{2}-\mathrm{PhCO}\right]^{+}, 66\right), 194$ (67), 181 (52), 180 (53), 168 (51), 152 (25), 105([PhCO $\left.]^{+}, 100\right)$.

*Assignment supported by $\mathrm{H} / \mathrm{C}$ correlation spectra. 


\section{X-ray Crystallography.}

All structures were solved and refined with SHELX-97. ${ }^{49}$ Non-hydrogen atoms were assigned anisotropic displacement parameters. $\mathrm{H}$ atoms positions were located and refined with isotropic displacement parameters. Molecular geometry calculations were made with PLATON, ${ }^{50}$ and illustrations were made ORTEP- $3^{51}$ and POVRAY. ${ }^{52}$

Crystal data for 11A: $\mathrm{C}_{18} \mathrm{H}_{15} \mathrm{NO}_{2}, \mathrm{M}_{\mathrm{r}}=277.32$, triclinic, $\mathrm{a}=10.153(3), \mathrm{b}=13.179(7)$, $\mathrm{c}$

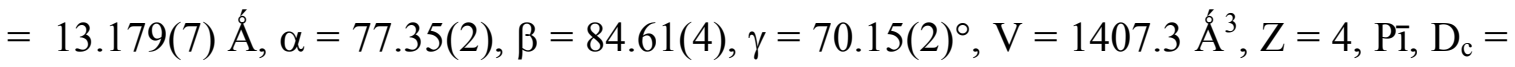
$1.31 \mathrm{gcm}^{-3}, \mu(\mathrm{MoK} \alpha)=0.08 \mathrm{~mm}^{-1}, \mathrm{~T}=100 \mathrm{~K}, 6320$ unique reflections, 5294 with $\mathrm{F}_{\mathrm{o}}>$ $4 \sigma\left(F_{o}\right), R=0.040, w R=0.104$. Crystals from methanol.

Crystal data for 11B: $\mathrm{C}_{18} \mathrm{H}_{15} \mathrm{NO}_{2}, \mathrm{M}_{\mathrm{r}}=277.32$, monoclinic, $\mathrm{a}=9.9997(2), \mathrm{b}=$ 13.1284(2), $\mathrm{c}=21.6474(3) \AA \dot{A}, \beta=95.7020(10), \mathrm{V}=2827.8 \AA^{3}, \mathrm{Z}=8, \mathrm{P} 2{ }_{1} / \mathrm{n}, \mathrm{D}_{\mathrm{c}}=1.30$ $\mathrm{gcm}^{-3}, \mu(\mathrm{MoK} \alpha)=0.08 \mathrm{~mm}^{-1}, \mathrm{~T}=100 \mathrm{~K}, 6211$ unique reflections, 4157 with $\mathrm{F}_{\mathrm{o}}>$ $4 \sigma\left(\mathrm{F}_{\mathrm{o}}\right), \mathrm{R}=0.037, \mathrm{wR}=0.080$. Long rods from ethyl acetate.

Crystal data for 11C: $\mathrm{C}_{18} \mathrm{H}_{15} \mathrm{NO}_{2}, \mathrm{M}_{\mathrm{r}}=277.32$, triclinic, $\mathrm{a}=9.7709(4), \mathrm{b}=12.8905(5)$, c $=13.2494(6) \AA ́ \AA, \alpha=70.822(2), \beta=68.573(2), \gamma=76.360(2)^{\circ}, \mathrm{V}=1454.45 \AA^{3}, \mathrm{Z}=4, \mathrm{P} \overline{1}$, $\mathrm{D}_{\mathrm{c}}=1.27 \mathrm{gcm}^{-3}, \mu(\mathrm{MoK} \alpha)=0.08 \mathrm{~mm}^{-1}, \mathrm{~T}=150 \mathrm{~K}, 6430$ unique reflections, 3576 with $F_{o}>4 \sigma\left(F_{o}\right), R=0.064, w R=0.152$. Crystals from acetone. One of the two independent molecules in the asymmetric unit is orientationally disordered over two positions with relative populations 17:3. 
Crystal data for 12: $\mathrm{C}_{19} \mathrm{H}_{18} \mathrm{~N}_{2} \mathrm{O}, \mathrm{M}_{\mathrm{r}}=290.36$, monoclinic, $\mathrm{a}=9.3770(2), \mathrm{b}=9.7055(2), \mathrm{c}$ $=16.7953(3) \AA \hat{\prime}, \beta=91.3607(12)^{\circ}, \mathrm{V}=1528.08 \AA^{3}, \mathrm{Z}=4, \mathrm{P} 2_{1} / \mathrm{c}, \mathrm{D}_{\mathrm{c}}=1.26 \mathrm{gcm}^{-3}, \mu$ $(\mathrm{MoK} \alpha)=0.08 \mathrm{~mm}^{-1}, \mathrm{~T}=120 \mathrm{~K}, 3504$ unique reflections, 2884 with $\mathrm{F}_{\mathrm{o}}>4 \sigma\left(\mathrm{F}_{\mathrm{o}}\right), \mathrm{R}=$ 0.045, $\mathrm{wR}=0.119$. Crystals from ethyl acetate.

Crystal data for 13: $\mathrm{C}_{26} \mathrm{H}_{23} \mathrm{~N}_{3} \mathrm{O}_{2}, \mathrm{M}_{\mathrm{r}}=409.48$, triclinic, $\mathrm{a}=9.8308(2), \mathrm{b}=9.6640(3), \mathrm{c}=$ 12.0688(3) $\AA$ \&́, $\alpha=85.4547(15), \beta=68.6506(14), \gamma=78.8152(15)^{\circ}, V=1047.58 \AA^{3}, Z=$ 2, $\mathrm{P} \overline{1}, \mathrm{D}_{\mathrm{c}}=1.30 \mathrm{gcm}^{-3}, \mu(\mathrm{MoK} \alpha)=0.08 \mathrm{~mm}^{-1}, \mathrm{~T}=120 \mathrm{~K}, 4800$ unique reflections, 3570 with $F_{o}>4 \sigma\left(F_{o}\right), R=0.051, w R=0.124$. Crystals from ethanol. (It is interesting to note a short contact across the centre of symmetry between two para carbon atoms of ring A (C15----C15: 3.056(2) Å), which is accompanied by edge to face contacts between the attached $\mathrm{H} 15$ atoms which are directed to the centroids of the [C5-C10] naphthalene rings (H15 ....centroid: $2.86 \AA$ ).

Crystal data for 17: $\mathrm{C}_{14} \mathrm{H}_{14} \mathrm{~N}_{2} \mathrm{O}_{2}, \mathrm{M}_{\mathrm{r}}=242.27$, monoclinic, $\mathrm{a}=15.8700(3), \mathrm{b}=$ 5.4817(1), $\mathrm{c}=28.7715(8) \AA ̊ ㇒=101.0295(8), \mathrm{V}=2456.7(1) \AA^{3}, \mathrm{Z}=8, \mathrm{C} 2 / \mathrm{c}, \mathrm{D}_{\mathrm{c}}=1.31$ $\mathrm{g} \mathrm{cm}^{-3}, \mu(\mathrm{MoK} \alpha)=0.09 \mathrm{~mm}^{-1}, \mathrm{~T}=120 \mathrm{~K}, 2785$ unique reflections, 2023 with $\mathrm{F}_{\mathrm{o}}>$ $4 \sigma\left(\mathrm{F}_{\mathrm{o}}\right), \mathrm{R}=0.048, \mathrm{wR}=0.127$. Crystals from ethyl acetate / hexane 1:2.

Crystal data for 18: $\mathrm{C}_{15} \mathrm{H}_{16} \mathrm{~N}_{2} \mathrm{O}_{2}, \mathrm{M}_{\mathrm{r}}=256.30$, monoclinic, $\mathrm{a}=10.3347(3), \mathrm{b}=$ 7.0992(2), $\mathrm{c}=18.2556(5) \AA \hat{,}, \beta=102.897(2), \mathrm{V}=1305.59(6) \AA^{3}, \mathrm{Z}=4, \mathrm{P} 2_{1} / \mathrm{n}, \mathrm{D}_{\mathrm{c}}=1.30$ 
$\mathrm{g} \mathrm{cm}^{-3}, \mu(\mathrm{MoK} \alpha)=0.09 \mathrm{~mm}^{-1}, \mathrm{~T}=120 \mathrm{~K}, 2981$ unique reflections, 2600 with $\mathrm{F}_{\mathrm{o}}>$ $4 \sigma\left(F_{o}\right), R=0.055, w R=0.163$. Crystals from ether.

Crystal data for 22: $\mathrm{C}_{21} \mathrm{H}_{18} \mathrm{~N}_{2} \mathrm{O}_{3}, \mathrm{M}_{\mathrm{r}}=346.37$, monoclinic, $\mathrm{a}=7.7283(2), \mathrm{b}=$ 13.6696(4), $\mathrm{c}=15.7465(6) \AA \hat{,}, \beta=95.5779(12), \mathrm{V}=1655.63(9) \AA^{3}, \mathrm{Z}=4, \mathrm{P} 2_{1} / \mathrm{c}, \mathrm{D}_{\mathrm{c}}=$ $1.39 \mathrm{~g} \mathrm{~cm}^{-3}, \mu(\mathrm{MoK} \alpha)=0.09 \mathrm{~mm}^{-1}, \mathrm{~T}=120 \mathrm{~K}, 3764$ unique reflections, 2820 with $\mathrm{F}_{\mathrm{o}}>$ $4 \sigma\left(F_{0}\right), R=0.047, w R=0.125$. Crystals from acetonitrile.

\section{Acknowledgements.}

We thank the EPSRC for a studentship (JO). We thank the EPSRC X-ray Crystallography Service for datasets, and the EPSRC Mass Spectrometry Service for mass spectral measurements. We thank Dr N. Brooks and Oxford Diffraction Ltd for a low temperature X-ray dataset. We thank the Dept Chemistry, University of Warwick, Dr Oliver Howarth and Mr. R. Jenkins, and JEOL Ltd and Dr P Meadows for some detailed high field NMR studies. We thank a referee for helpful comments.

\section{References.}

1. H.B Bürgi, J.D. Dunitz and E. Schefter, J. Amer. Chem. Soc., 1973, 95, 5065.

2. H.B. Bürgi and J.D. Dunitz, in "Structure Correlation" ed. H.B. Burgi, J.D. Dunitz, VCH, Weinheim, 1994, pp 205.

3. A.S. Cieplak, in "Structure Correlation" ed. H.B. Burgi, J.D. Dunitz, VCH, Weinheim, 1994, pp 205.

4. W.B. Schweizer, G. Procter, M. Kaftory, M. and J.D. Dunitz, Helv. Chim. Acta, 1978, 61, 2783. 
5. P.C. Bell and J.D. Wallis, J. Chem. Soc., Chem. Commun., 1999, 257.

6. J. O'Leary, P.C. Bell, J.D. Wallis and W.B. Schweizer, J. Chem. Soc., Perkin Trans. 2, 2001, 133.

7. P.C. Bell, M. Drameh, N. Hanly and J.D. Wallis, Acta Crystallogr., 2000, C56, 670.

8. J. Clayden, C. McCarthy and M. Helliwell, Chem. Commun., 1999, 2059.

9. D.R.W. Hodgson, A.J. Kirby and N. Feeder, J. Chem. Soc. Perkin Trans 1, 1999, 949.

10. A.C. Blackburn and R.E. Gerkin, Acta Crystallogr., 1997, C53, 1077.

11. J.C. Galluci, D.J. Hart and G.J. Young, Acta Crystallogr., 1998, B54, 73.

12. P.C. Bell, W. Skranc, X. Formosa, J. O’Leary and J.D. Wallis, J. Chem. Soc. Perkin Trans 2, 2002, 878.

13. M. Parvez and I.I. Schuster, Acta Crytallogr., 1990, C46, 947; G. Procter, D. Britton, and J.D. Dunitz, Helv. Chim Acta, 1981, 64, 471.

14. A. Panda, G. Mugesh, H.B. Singh and R.J. Butcher, Organometallics, 1999, 18, 1986.

15. C. Breliere, F. Carre, R.J.P. Corriu, M. Poirier and G. Royo, Organometallics, 1986, 5, 388; F. Carre, G.Cerveau, C. Chuit, R.J.P.Corriu and C. Reye, New J. Chem., 1992, 16, 63; C. Breliere, F. Carre, R.J.P. Corriu, W.E. Douglas, M. Poirier, G. Royo, and M.W.C. Man, Organometallics, 1992, 11, 1586; F. Carre, R.J.P. Corriu, A. Kpoton, M. Poirier, G. Royo, J.C. Young and C. Belin, J. Organomet. Chem., 1994, 470, 43.

16. C. Cox, H. Wack and T. Lectka, Angew. Chem., Int. Ed. Engl., 1999, 38, 798.

17. P.R. Mallison, G.T. Smith, C.C. Wilson, E. Grech and K. Wozniak, J. Amer. Chem. Soc., 2003, 125, 4259; K. Wozniak, P.R. Mallinson, G.T. Smith, C.C. Wilson and E. Grech, J. Phys. Org. Chem., 2003, 16, 764.

18. P. Hodgson, G.C. Lloyd-Jones, M. Murray, T.M. Peakman and R.L.Woodward, Chem. Eur., 2000, 6, 4451.

19. K. Akiba, M. Yamashita, Y. Yamamoto and S. Nagase, J. Amer. Chem. Soc., 1999, 121, 10644; M. Yamashita, Y. Yamamoto, K. Akiba, D. Hashizume, F. Iwasaki, N. Takagi, S. Nagase, J. Amer. Chem. Soc., 2005, 127, 4354. 
20. M. Yamashita, K. Kamura, Y. Yamamoto and K. Akiba, Chem. Eur. J., 2002, 8, 2976.

21. J.E. Davies, A.J. Kirby and I.V. Komarov, Helv. Chim. Acta, 2003, 86, 1222; A.J. Kirby, I.V. Komarov, V.A. Bilenko, J.E. Davies and J.M. Rawson, Chem. Commun., 2002, 2106.

22. K.A. Lyssenko, S.M. Aldoshin and M.Y. Antipin, Mendeleev Comm., 2004, 98.

23. C.S. Frampton, H. Straver, J. D. Wallis and S.C.Coles, in preparation.

24. Cambridge Structural Database, F.H Allen, Acta Crystallogr., 2002, B58, 380.

25. H.J. Wasserman, R.R. Ryan, S.P. Layne, Acta Crystallogr., 1985, C41, 783.

26. D. Hashizume, N. Miki, T. Yamazaki, Y. Aoyagi, T. Arisato, H. Uchiyama, T. Endo, M. Yasui and F. Iwasaki, Acta Crystallogr., 2003, B59, 404.

27. T.J. Kidd, T.J.A. Loontjens, D.A. Leigh and J.K.Y. Wong, Angew. Chem., Int. Ed. Engl., 2003, 42, 3379.

28. M. Iwata, H. Nagase, T. Endo and H. Ueda, Acta Crystallogr., 1997, C53, 329.

29. T. Koch and M. Hesse, Synthesis, 1995, 251.

30. O.Carugo, G. Poli and L. Manzoni, Acta Crystallogr., 1992, C48, 2013.

31. S.-G. Roh and J.H. Jeong, Acta Crystallogr., 2000, C56, e529.

32. Nitro groups are attached to $\mathrm{sp}^{3} \mathrm{C}$ atoms, structures measured at $\mathrm{T} \leq 130 \mathrm{~K}$.

33. M Reetz, S. Hutte and F Goddard, Z. Naturforsch B, 1995, 50, 415.

34. M. Sievert, N. Nagel, H. Bock and R. Dienelt, Acta Crystallogr., 1999, C55, 1147.

35. T.D. Ladyzhnikova, A.G. Tyrkov, K.V. Altukhov, V.P. Pozdnyakov, M.O. Dekaprilevich and K.I. Rezchikova, Zh. Org. Khim, 1992, 28, 912.

36. P.Veya, C. Floriani, A. Chiesi-Villa and C. Guastini, Organometallics, 1991, 10, 1652 ; P.Veya, C. Floriani, A. Chiesi-Villa and C. Rizzolo, Organometallics, 1994, 13, 214.

37. L.R. Favello, S. Hicke and T.E. Mueller, Acta Crystallogr., 1995, C51, 859.

38. H. Bock and N. Nagel, Z. Naturforsch B, Chem. Sci., 1998, 53, 792.

39. The structure measured at higher temperature may show a very small apparent shortening of bonds due to the effects of thermal motion, but this should be rather small for these temperatures. 
40. N. Nishiwaki, T. Nogami, C. Tanaka, F. Nakashima, Y. Inoue, N. Asaka, Y. Tohda and M. Ariga, J. Org. Chem., 1999, 64, 2160.

41. W.R. Bowman, B.T. Golding and W.P. Watson, J. Chem. Soc. Perkin Trans. 2, 1980,731 .

42. M. Pilkington, J.D. Wallis, G.T. Smith and J.A.K. Howard, J. Chem. Soc. Perkin 2, 1996, 1849; G.T. Smith, J.A.K. Howard, J.D. Wallis, Phys. Chem. Chem. Phys., $2001,3,4501$.

43. G.C. Lloyd-Jones, J.N. Harvey, P. Hodgson, M. Murray, R.L. Woodward, Chem. Eur. J., 2003, 9, 4523.

44. R. Glaser, C. Horan, Can. J. Chem., 1996, 74, 1200; C.J. Horan, C.L. Barnes, R. Glaser, Chem. Ber., 1993, 126, 243; C.J. Horan, C.L. Barnes, R. Glaser, Acta Crystallogr., 1993, C49, 507; C.J. Horan, P. E. Haney, C.L. Barnes, R. Glaser, Acta Crystallogr., 1993, C49, 1525; R. Glaser, C.J. Horan, E.D. Nelson, M.K. Hall, J. Org. Chem., 1992, 57, 215.

45. J.Z. Gougoutas, Cryst. Struct. Commun., 1982, 11, 1305 \& 1978, 7, 183; J.Z. Gougoutas, J. Amer. Chem. Soc., 1979, 101, 5672; J.Z. Gougoutas, J. Johnson, J. Amer. Chem. Soc., 1978, 100, 5816.

46. J. D. Wallis, J.D. Dunitz, Helv. Chim. Acta, 1993, 76, 1411.

47. C.P. Brock, J.D. Dunitz, Acta Crystallogr., 1982, B38, 2218.

48. A. J. Kirby and J. M. Percy, Tetrahedron, 1988, 44, 6903.

49. G.M. Sheldrick, SHELX97, Program for the solution and refinement of crystal structures, University of Gottingen, Germany, 1997.

50. L. Farrugia, PLATON (A.L. Spek, University of Utrecht) for Windows, University of Glasgow, 2004.

51. C.K. Johnson, M.N. Burnett, ORTEPIII Report ORNL-6895, Oak Ridge National Laboratory, Tennessee, USA.

52. POVRAY, Persistence of Vision Ray Tracer graphics program, www.povray.org. 